\title{
Article \\ DHA-Rich Aurantiochytrium Biomass, a Novel Dietary Supplement, Resists Degradation by Rumen Microbiota without Disrupting Microbial Activity
}

\author{
Teemu Rinttilä ${ }^{1, *(\mathbb{D})}$, Colm A. Moran ${ }^{2}(\mathbb{D})$ and Juha Apajalahti $^{1}(\mathbb{D})$ \\ 1 Alimetrics Research Ltd., Koskelontie 19B, FI-02920 Espoo, Finland; j.apajalahti@alimetrics.com \\ 2 Alltech SARL, Rue Charles Amand, 14500 Vire, France; cmoran@alltech.com \\ * Correspondence: teemu.rinttila@alimetrics.com
}

\section{check for}

updates

Citation: Rinttilä, T.; Moran, C.A.; Apajalahti, J. DHA-Rich

Aurantiochytrium Biomass, a Novel Dietary Supplement, Resists

Degradation by Rumen Microbiota without Disrupting Microbial

Activity. Appl. Microbiol. 2022, 2,

53-72. https://doi.org/10.3390/

applmicrobiol2010004

Academic Editor: Kateřina

Olša Fliegerová

Received: 11 November 2021

Accepted: 4 January 2022

Published: 7 January 2022

Publisher's Note: MDPI stays neutral with regard to jurisdictional claims in published maps and institutional affiliations.

Copyright: (c) 2022 by the authors. Licensee MDPI, Basel, Switzerland. This article is an open access article distributed under the terms and conditions of the Creative Commons Attribution (CC BY) license (https:// creativecommons.org/licenses/by/ $4.0 /)$.

\begin{abstract}
We first sought to evaluate the effect of dietary supplementation with the docosahexaenoic acid (DHA)-rich microalgae, Aurantiochytrium limacinum (AURA), on rumen fermentation and the resistance of DHA to degradation and biohydrogenation by rumen microbes through ex vivo fermentation experiments. Subsequently, we sought to quantify the diet-derived DHA content of milk and the impact of AURA on microbial composition and metabolism in a pilot feeding trial with rumen-cannulated dairy cows. To achieve our aims, rumen fluid from cannulated cows was used as inoculum, and the effect of AURA inclusion on fermentation ex vivo was examined. At doses corresponding to the amount of AURA recommended for commercial production animals, only $\sim 10 \%$ of DHA was degraded or biohydrogenated by rumen microorganisms. The results show that feeding with AURA had no effect on either total bacterial density or short-chain fatty acid production. Real-time quantitative PCR analysis of the rumen fluid samples collected during a seven-week in vivo trial revealed that microbes related to lactic acid metabolism and methanogenesis were significantly suppressed by the AURA-supplemented diet. The DHA concentration in milk increased over 25-fold with the AURA-supplemented diet and dropped by $30-40 \%$ within one week of washout. The addition of A. limacinum biomass to dairy cow diets resulted in positive effects on rumen microbial composition with no adverse effect on fermentation activity. AURA-derived DHA was stable, with only modest degradation in the rumen, and was successfully deposited in milk. This is the first study to investigate the effect of supplementing the diet of dairy cows with a protist-based biomass, namely, on important rumen fermentation parameters and on DHA deposition in milk, using a combination of ex vivo and in vivo approaches.
\end{abstract}

Keywords: Aurantiochytrium limacinum; DHA; dietary supplement; rumen microbiota; polyunsaturated fatty acids; dairy cows

\section{Introduction}

Clinical data indicate that, in humans, the excessive intake of saturated fatty acids increases the risk of developing chronic diseases, including cardiovascular disease (CVD) and type II diabetes, and may play a role in the onset of neurodegenerative disorders, such as Alzheimer's disease [1-4]. Significant proportions of saturated fats in the human diet come from ruminant meat, milk, and milk-based products [5]. However, foods originating from ruminants also provide high-quality proteins, bioactive lipids, and essential vitamins and minerals to the human diet [6]. There is a direct correlation between healthy bioactive lipid composition in food products originating from ruminants and dietary fat composition [7-9]. Food enrichment with long-chain omega-3 polyunsaturated fatty acids (LC-PUFAs) can serve as a strategy to prevent or reduce the economic and social burden of the aforementioned chronic diseases, while retaining the dietary benefits associated with macro- and micronutrients in ruminant meat and milk products and, importantly, without requiring changes to consumer eating habits $[8,10]$. Meta-analyses of clinical studies have 
demonstrated a strong relationship between the consumption of LC-PUFAs, specifically docosahexaenoic acid (DHA; 22:6n-3) and eicosapentaenoic acid (EPA; 20:5n-3), and the reduced incidence of CVD, hypertension, certain autoimmune and inflammatory diseases, dementia, cancer, and all-cause mortality [11-15].

In dairy cows, fish meal (FM) and fish oils (FO) are the principal sources of dietary LC-PUFA EPA and DHA, neither of which are commonly found in dairy cow rations [10]. However, ingredients of fish origin tend to affect the oxidative stability of milk, show substantial variability in composition and quality, and are susceptible to contamination with lipophilic organic chemicals present in marine ecosystems [16]. These supplements can inhibit ruminal biohydrogenation of unsaturated fatty acids thus modifying the flow of fatty acids to the omasum, leading to substantive alterations in rumen microbiota and metabolism $[17,18]$. Moreover, the environmental sustainability of declining and fluctuating fish stocks needs to be considered when using FM and FO as sources of beneficial LCPUFAs [19]. There is an ongoing search for alternative PUFA ingredients, such as DHA-rich marine algae or thraustochytrids, as dietary supplements to increase PUFA availability in the food chain $[19,20]$.

The thraustochytrid Aurantiochytrium limacinum is a member of the heterotrophic protists, which are commonly (mis-)classified as microalgae, and also exhibit fungus-like characteristics [21]. These organisms are the primary producers of DHA in the pelagic food chain and can be heterotrophically mass-cultured for industrial purposes using suitable simple carbon sources and without the requirement for sunlight [22]. The synthesized DHA is accumulated as a constituent of triacylglycerols in intracellular lipid droplets within the unextracted biomass, offering protection against oxidation and thermal processing [23]. Introducing DHA-rich microbial biomass to the diet of ruminants can potentially improve the nutritional value of milk and meat products [8,24]. However, this will only succeed if dietary inclusion does not suppress rumen fermentation and, thus, lower the productivity of dairy cows $[18,25,26]$. It is also important for the introduced fatty acids to resist lipolytic degradation and/or biohydrogenation by rumen bacteria and bypass the rumen in an unsaturated form [26,27].

In the present study, we investigated the effect of an A. limacinum product (AURA) on rumen microbiota-mediated fermentation, which was measured via the production of gaseous and acidic metabolic end-products and the microbial biomass yield in an ex vivo rumen fermentation model. We also assessed the resistance of DHA, a fatty acid component of major interest in AURA products, to degradation and biohydrogenation by rumen microbes. Finally, we conducted a mechanistic seven-week pilot feeding trial with two rumen-cannulated dairy cows to verify the ex vivo findings and monitor diet-derived DHA deposition in milk. To our best knowledge, this is the first study to examine the effects of protist-based biomass on pivotal rumen fermentation parameters and the deposition of DHA in milk using a combination of ex vivo and in vivo approaches.

\section{Materials and Methods}

\subsection{Basal Diet for Ex Vivo Fermentation}

The basal diet used as substrate in the ex vivo fermentation studies was composed of fresh grass silage (energy $10.8 \mathrm{MJ} / \mathrm{kg}$, crude protein 16\%) and commercial dairy cow concentrate (Lypsykrossi, Suomen Rehu Ltd., Hyvinkää, Finland; energy $12.3 \mathrm{MJ} / \mathrm{kg}$, crude protein $19 \%)$, dosed 60:40 on a dry matter (DM) basis. The grass silage used was a combination of timothy (Phleum pratense) and meadow fescue (Festuca pratensis), cut into 3-8 $\mathrm{mm}$ pieces. A subsample of chopped silage was taken for DM determination, but fresh silage was used for the actual fermentation studies since drying is likely to affect fermentation kinetics. Commercial concentrate pellets based on oats, barley, wheat bran, rapeseed meal, sugar beet pulp, vitamins, and minerals were milled to ensure uniform particle size. The total amount of basal feed material was $0.25 \mathrm{~g}$ DM per vessel. Each feed component, including the AURA supplement, was separately weighed into individual fermentation vessels to ensure similar ratios. 


\subsection{Rumen Ex Vivo Protocol}

The two rumen-cannulated dairy cows used as donors of rumen fluid inoculum (one animal per experiment) were lactating at the time of sampling and were fed $8 \mathrm{~kg} \mathrm{DM}$ per day of a commercial compound feed (Opti-Maituri 26, Lantmännen Feed Oy, Turku, Finland; energy $12.8 \mathrm{MJ} / \mathrm{kg}$, crude protein $26 \%$ ) and approximately $40 \mathrm{~kg}$ of grass silage ( $13 \mathrm{~kg}$ DM with energy $10.8 \mathrm{MJ} / \mathrm{kg}$ and crude protein $16 \%$ ). Rumen fluid was collected from the middle part of the rumen before the first daily feeding using a vacuum pump. The rumen fluid was immediately sealed in an airtight thermos container, transported to the laboratory, and used as inoculum within one hour of collection. Prior to inoculation, large solid particles were removed from the fresh rumen fluid by was straining through a $3 \mathrm{~mm}$ steel mesh under protective anoxic gas flow.

Glass serum bottles $(20 \mathrm{~mL})$ were used as the fermentation vessels. The vessels, containing the feed components and test products, were flushed with $\mathrm{CO}_{2}$ gas that had been passed through a hot copper catalyst, to scavenge any residual $\mathrm{O}_{2}$, and sealed with thick butyl rubber stoppers. Fermentation was initiated by introducing temperature-adjusted $\left(+38{ }^{\circ} \mathrm{C}\right)$ anaerobic artificial saliva, including phosphate and bicarbonate, as buffering agents [28], and fresh rumen fluid (10\% inoculum) into the vessels to a total volume of $10 \mathrm{~mL}$ under protective $\mathrm{O}_{2}$-free $\mathrm{CO}_{2}$ gas flow. Finally, the vessels were sealed with butyl rubber stoppers and aluminum seals and incubated at $+38^{\circ} \mathrm{C}$ in a gyratory shaker at $100 \mathrm{rpm}$. The exact time of inoculation for each vessel was recorded and considered when sampling and stopping fermentation. Inoculation of the fermentation vessels was conducted in a random order to avoid any bias resulting from time of inoculation or freshness of the inoculum.

Gas production was measured at chosen timepoints by manually puncturing the rubber stopper with a needle that was connected to a high-precision glass syringe with a sensitive ground plunger and recording the volume of gas released from the fermentation vessels. In both ex vivo experiments, five replicate vessels of each dietary treatment were withdrawn from the study at each time point for various analyses. Thus, none of the test vessels was sampled during fermentation to avoid potential effects on fermentation kinetics. The total duration of the individual ex vivo experiments, and their intermediate sampling points, are described below.

\subsection{Ex Vivo Rumen Experiment I}

This ex vivo experiment examined changes in the overall abundance and stability of LC-PUFAs in the rumen environment that resulted from the A. limacinum (AURA) biomass test product (Alltech Inc., Nicholasville, KY, USA). The effect of the spray-dried AURA product on rumen fermentation was also assessed. Corresponding analyses were also performed on the ethyl acetate (EtOAc)-soluble fraction of the AURA product, which was obtained as follows: (1) $9.0 \mathrm{~g}$ of the AURA product was suspended in $\mathrm{H}_{2} \mathrm{O}$, (2) the $\mathrm{pH}$ was adjusted to 3 with $\mathrm{HCl}$, and water was added to a total added volume of $21 \mathrm{~mL}$, (3) $27 \mathrm{~mL}$ of EtOAc was added and the mixture was shaken at room temperature overnight, (4) the extract was centrifuged at $3000 \times g$ for $10 \mathrm{~min}$, (5) the organic phase was withdrawn and its volume was adjusted to $25 \mathrm{~mL}$ with fresh EtOAc, and (6) long-chain fatty acid (LCFA) composition was analyzed as described below. The volume of EtOAc extract used in the fermentation study was adjusted so that the LCFA content corresponded to that in the intact AURA product. The extract was introduced to empty vessels, and the solvent was evaporated to dryness before adding other components. For comparison, an FO product commonly used as a feed ingredient was tested in the experiment. The AURA and FO product doses are listed in Table 1. For all test products, the total LCFA additions were the same for doses 1 through 4 . The sampling time points in fermentation were 0 and $8 \mathrm{~h}$. 
Table 1. Experimental supplements introduced to the vessels used for ex vivo rumen fermentation.

\begin{tabular}{|c|c|c|c|c|}
\hline \multirow[b]{2}{*}{ Diet } & \multicolumn{2}{|c|}{ Basal Substrate } & \multicolumn{2}{|c|}{ Supplement Dosing } \\
\hline & $\begin{array}{l}\text { Grass Silage } \\
\text { (mg DM) }\end{array}$ & $\begin{array}{l}\text { Compound } \\
\text { Feed(mg DM) }\end{array}$ & $\mathrm{mg} / \mathrm{mL}^{*}$ & $\begin{array}{l}\text { LCFA \% of } \\
\text { Diet DM }{ }^{\dagger}\end{array}$ \\
\hline \multicolumn{5}{|l|}{ Ex vivo experiment I } \\
\hline Control & 150 & 100 & - & 0 \\
\hline AURA dose 1 & 150 & 100 & 0.08 & 0.16 \\
\hline AURA dose 2 & 150 & 100 & 0.15 & 0.32 \\
\hline AURA dose 3 & 150 & 100 & 0.30 & 0.64 \\
\hline AURA dose 4 & 150 & 100 & 0.60 & 1.27 \\
\hline AURA extract dose 1 & 150 & 100 & $\ddagger$ & 0.16 \\
\hline AURA extract dose 2 & 150 & 100 & $\ddagger$ & 0.32 \\
\hline AURA extract dose 3 & 150 & 100 & $\ddagger$ & 0.64 \\
\hline AURA extract dose 4 & 150 & 100 & $\ddagger$ & 1.27 \\
\hline Fish oil dose 1 & 150 & 100 & 0.05 & 0.16 \\
\hline Fish oil dose 2 & 150 & 100 & 0.11 & 0.32 \\
\hline Fish oil dose 3 & 150 & 100 & 0.22 & 0.64 \\
\hline Fish oil dose 4 & 150 & 100 & 0.44 & 1.27 \\
\hline \multicolumn{5}{|l|}{ Ex vivo experiment II } \\
\hline Control & 150 & 100 & - & 0 \\
\hline AURA dose 1 & 150 & 100 & 0.25 & 1.0 \\
\hline AURA dose 2 & 150 & 100 & 0.63 & 2.5 \\
\hline AURA dose 3 & 150 & 100 & 1.50 & 5.7 \\
\hline AURA dose 4 & 150 & 100 & 2.50 & 9.1 \\
\hline
\end{tabular}

${ }^{*}$ Concentration of product in fermentation medium. ${ }^{+}$LCFA concentration of supplement in dry feed. ${ }^{\ddagger}$ Doses 1 to 4 of AURA extract have the same total concentration of C12-C24 acids as doses 1 to 4 of AURA.

\subsection{Ex Vivo Rumen Experiment II}

In this experiment, we measured the dose-response relationship of the AURA test product with rumen fermentation and the resistance of DHA to bacterial attack by rumen microbes by using a wider AURA product concentration range than that used in experiment I. The exact concentrations of AURA used are listed in Table 1. In experiment II, the sampling time points were 0,4 , and $8 \mathrm{~h}$ of fermentation.

\subsection{In Vivo Experiment with Rumen-Cannulated Cows-Animals, Trial Schedule, and Dietary Treatments}

Two rumen-cannulated lactating dairy cows were assigned to the in vivo study. The animals were kept in the research facility of Alimetrics Ltd. in Southern Finland, in accordance with EU Directive 2010/63/EU, and cannulation was approved by the Animal Experiment Board in Finland. The animals were kept in a herd of approximately 30 dairy cows in a loose-stall system and used in a seven-week trial comprising three feeding phases: (1) a two-week pre-trial control diet, (2) a four-week AURA diet, and (3) a one-week washout phase. The diet used for both the control and the washout phase was that used routinely on the farm: 7-8 kg of oat-based compound feed and grass silage fed ad libitum ( $\sim 8 \mathrm{~kg} \mathrm{DM})$. During the compound feeding period, the experimental animals were tied within individual stalls. Since the normal diet of the experimental cows did not change, no adaptation period was required prior to the start of the trial. During the AURA diet period, the spray-dried product ( $140 \mathrm{~g} / \mathrm{head} /$ day) was manually mixed into the compound feed every day and served in four portions. Grass silage was always freely available to the animals, except when the compound feed was served.

\subsection{Sampling of Rumen Fluid and Milk}

A vacuum pump was used to collect rumen fluid samples (each $100 \mathrm{~mL}$ ) for shortchain fatty acid (SCFA) and microbial analyses through the cannula of both animals in the morning of four consecutive days during the final week of each dietary phase (control, AURA, washout) of the trial. The samples were drawn from the mid-ventral region of the 
rumen immediately prior to the first feeding of each day and then immediately frozen on dry ice. To analyze the LCFA content in milk, a $100 \mathrm{~mL}$ sample was drawn during both morning and evening milking on two consecutive days during each week of the three dietary phases and then frozen on dry ice. Prior to LCFA analysis in the laboratory, the samples from each day (morning and evening sample) were thawed and pooled at a ratio corresponding to the respective volumes of milk obtained in the morning and evening milking.

\subsection{Analysis of Short-Chain Fatty Acids in Rumen Fluid}

Volatile fatty acids (VFA) and lactic acid, referred to hereafter as SCFA, were analyzed as free acids in the rumen fluid samples from both ex vivo and in vivo experiments using pivalic acid (Sigma-Aldrich, St. Louis, MO, USA) as an internal standard [29]. For this, $400 \mu \mathrm{L}$ of rumen fluid and $2.4 \mathrm{~mL}$ of $1.0 \mathrm{mM}$ pivalic acid solution were mixed, shaken vigorously for $5 \mathrm{~min}$, and centrifuged at $3000 \times g$ for $10 \mathrm{~min}$. Then, $800 \mu \mathrm{L}$ of the supernatant was mixed with $400 \mu \mathrm{L}$ of saturated oxalic acid solution, incubated at $4{ }^{\circ} \mathrm{C}$ for $60 \mathrm{~min}$, and centrifuged at $18,000 \times g$ for $10 \mathrm{~min}$. The supernatant was analyzed by gas chromatography (Agilent Technologies, Santa Clara, CA, USA) using a glass column packed with 80/120 Carbopack B-DA/4\% Carbowax stationary phase, helium as the carrier gas, and a flame ionization detector. The quantified acids were acetic, propionic, butyric, valeric, isobutyric, 2-methylbutyric, isovaleric, and lactic acid.

\subsection{Extraction of Microbial DNA from Rumen Fluid Samples}

Rumen fluid subsamples from ex vivo experiment II and the in vivo trial were collected for analysis of the abundance of different microbial species, groups, or genera via real-time quantitative PCR (qPCR). Microbial DNA was extracted from rumen fluid using the following protocol. First, $0.4 \mathrm{~mL}$ of each rumen fluid sample was suspended in $1.6 \mathrm{~mL}$ of $50 \mathrm{mM}$ phosphate-buffered saline with EDTA, and the suspension was shaken vigorously for $2 \mathrm{~min}$. Next, the microcentrifuge tubes were centrifuged at $18,000 \times g$ for $10 \mathrm{~min}$ to pellet the microbial cells, after which the pellet was resuspended in $600 \mu \mathrm{L}$ of phosphate lysis buffer with $100 \mathrm{mM}$ Tris and $50 \mathrm{mM}$ EDTA ( $\mathrm{pH}$ 8.0). The suspension was transferred to a screw-cap microcentrifuge tube containing $20 \mu \mathrm{L}$ of proteinase $\mathrm{K}$ ( $20 \mathrm{mg} / \mathrm{mL}$; Roche Diagnostics $\mathrm{GmbH}$, Mannheim, Germany) and $0.4 \mathrm{~g}$ of sterile glass beads (Scientific Industries Inc., Bohemia, NY, USA), and incubated at $65^{\circ} \mathrm{C}$ for $60 \mathrm{~min}$ with shaking for $30 \mathrm{~s}$ (1400 rpm) at $10 \mathrm{~min}$ intervals. The microbial cells were disrupted by two $1 \mathrm{~min}$ rounds of bead beating (FastPrep-24 ${ }^{\mathrm{TM}}$, MP Biomedicals, Irvine, CA, USA) at $6.5 \mathrm{~m} / \mathrm{s}$, after which genomic DNA was purified from the homogenates through phenol-chloroform-isoamyl alcohol (24:1) extraction with centrifugation at $10,000 \times g$ for $10 \mathrm{~min}$, followed by chloroform-isoamyl alcohol purification with centrifugation at $10,000 \times g$ for $10 \mathrm{~min}$. The DNA was precipitated by the addition of 0.6 volumes of $100 \%$ isopropanol and pelleted by centrifugation at $18,000 \times g$ for $10 \mathrm{~min}$. Finally, the DNA pellet was washed twice with $1 \mathrm{~mL}$ of ice-cold $70 \%$ ethanol, dried, and resuspended in $100 \mu \mathrm{L}$ of Tris-EDTA buffer with $10 \mathrm{mM}$ Tris and 1.0 mM EDTA (pH 8.0) (AppliChem, Darmstadt, Germany).

\section{9. qPCR Analysis of Rumen Microorganisms}

qPCR analyses were performed using an ABI Prism Sequence Detection System 7500 instrument (Thermo Fisher Scientific Inc., Waltham, MA, USA). Amplifications were conducted in $15 \mu \mathrm{L}$ volumes with SYBR Select Master Mix (Thermo Fisher Scientific Inc., Waltham, MA, USA), $0.25 \mu \mathrm{M}$ of both primers, and $5 \mu \mathrm{L}$ of 1:100 diluted template DNA or deionized sterile water as a no-template control. The rRNA gene-targeted primer sequences and PCR product sizes used for enumeration of the target microorganisms are listed in Table 2. The thermal cycling conditions involved one cycle of preheating at $50{ }^{\circ} \mathrm{C}$ for $2 \mathrm{~min}$ and an initial denaturation at $95^{\circ} \mathrm{C}$ for $10 \mathrm{~min}$, followed by 40 cycles of denaturation at $95^{\circ} \mathrm{C}$ for $15 \mathrm{~s}$ and annealing and extension at the primer-specific annealing temperatures for $60 \mathrm{~s}$. To verify the specificity of amplifications based on the melting temperature of 
PCR products, a melt curve analysis was carried out in conjunction with each qPCR run by slowly decreasing the temperature from 95 to $60^{\circ} \mathrm{C}$, with fluorescence determination at $0.3{ }^{\circ} \mathrm{C}$ intervals.

Table 2. Real-time quantitative PCR assays used in the study.

\begin{tabular}{|c|c|c|c|}
\hline Target Microorganism or Group & Primer Sequence $\left(5^{\prime}-3^{\prime}\right)$ & Product Size (bp) & Reference \\
\hline Total eubacteria & $\begin{array}{c}\text { F: TCCTACGGGAGGCAGCAGT } \\
\text { R: GGACTACCAGGGTATCTAATCCTGTT }\end{array}$ & 466 & {$[30]$} \\
\hline Methanogens & $\begin{array}{l}\text { F: AATTGGCGGGGGAGCAC } \\
\text { R: GGCCATGCACCWCCTCTC }\end{array}$ & 136 & {$[31]$} \\
\hline Lachnospiraceae & $\begin{array}{l}\text { F: GACRGTACCTGACTAAGAAGC } \\
\text { R: TTTGAGTTTCATTCTTGCGAA }\end{array}$ & 435 & Unpublished \\
\hline Ruminococcaceae & $\begin{array}{l}\text { F: CGCACAAGCRGTGGAGT } \\
\text { R: ACCTTCCTCCGTTTTGTCAA }\end{array}$ & 249 & Unpublished \\
\hline Bacteroides-Prevotella & $\begin{array}{l}\text { F: GGTGTCGGCTTAAGTGCCAT } \\
\text { R: CGGAYGTAAGGGCCGTGC }\end{array}$ & 140 & {$[32]$} \\
\hline Lactobacillus spp. & $\begin{array}{c}\text { F: AGCAGTAGGGAATCTTCCA } \\
\text { R: CACCGCTACACATGGAG }\end{array}$ & 341 & {$[32]$} \\
\hline Streptococcus spp. & $\begin{array}{l}\text { F: GGGGATAACTATTGGAAACGATA } \\
\text { R: CCWACTAGCTAATACAACGCA }\end{array}$ & 118 & Unpublished \\
\hline Veillonella spp. & $\begin{array}{c}\text { F: AYCAACCTGCCCTTCAGA } \\
\text { R: CGTCCCGATTAACAGAGCTT }\end{array}$ & 343 & {$[32]$} \\
\hline Selenomonas ruminantium & $\begin{array}{l}\text { F: GATTAAAGATGGCCTCTACTTG } \\
\text { R: CGTCAACAGAGCTTTACGAG }\end{array}$ & 253 & Unpublished \\
\hline Fibrobacter succinogenes & $\begin{array}{l}\text { F: GGTATGGGATGAGCTTGC } \\
\text { R: GCCTGCCCCTGAACTATC }\end{array}$ & 446 & {$[33]$} \\
\hline Megasphaera elsdenii & $\begin{array}{l}\text { F: GGGTGAGTAACGCGTAAGCAA } \\
\text { R: CTGCCATGCGACAAAAAGAA }\end{array}$ & 93 & Unpublished \\
\hline Total protozoa & $\begin{array}{l}\text { F: GCTTTCGWTGGTAGTGTATT } \\
\text { R: CTTGCCCTCYAATCGTWCT }\end{array}$ & 223 & {$[34]$} \\
\hline
\end{tabular}

Tenfold serial dilutions ranging from $1 \times 10^{8}$ to $1 \times 10^{2}$ synthetic small-subunit rRNA gene copies of target microorganism (gBlocks ${ }^{\circledR}$ Gene Fragments, IDT, Coralville, IA, USA) were included in each 96-well plate. The fractional cycle number at which the fluorescence passed the threshold (set at 0.3 fluorescence units) was determined for the unknowns and compared with the standard curves. Taking into account the original volume of the starting material, elution volume, and PCR template dilution, the numbers of small-subunit rRNA gene targets were determined per $\mathrm{mL}$ of rumen fluid. For data analysis, the rRNA gene copies $/ \mathrm{mL}$ values were $\log _{10}$-transformed to achieve a normal distribution.

\subsection{LCFA Analysis of Rumen Fluid and Milk Samples}

DHA and other LCFAs were analyzed in the test products (FO, AURA, and the EtOAc extract of AURA), the ex vivo rumen fluid simulation samples, and the milk samples from the in vivo feeding trial. The samples were prepared according to a previously described procedure [35] and analyzed on an Agilent 7890 gas chromatograph equipped with a 5975C Mass Selective Detector (Agilent Technologies, Santa Clara, CA, USA).

\subsection{Statistical Analysis}

\subsubsection{Ex Vivo Results}

To enable statistical comparisons between the different test product doses and time points, Tukey's honestly significant difference (HSD) post hoc test was performed following an analysis of variance (ANOVA) of the ex vivo simulation data with the type I error rate set to $\alpha=0.05$. The statistical significance of the change in the residual concentration of each LCFA characteristic within each test product during $8 \mathrm{~h}$ of fermentation in ex vivo experiment I was determined through an independent sample $t$-test, which was performed separately for each test product and dose. This approach was used because the 
objective was to discover the potential concentration change in each individual acid during fermentation, rather than an overall change in acid composition.

\subsubsection{In Vivo Results}

The mechanistic feeding trial involved two cows, which were in synchrony for two weeks on the control diet, then for four weeks on the AURA diet and, finally, for one week on the control diet (washout). When we statistically analyzed the effects of the AURA test product on the rumen microbial parameters, we compared data from samples collected during the final week of each feeding period (control, AURA, washout); in practice, we compared the means of data generated from samples collected on four consecutive days in weeks two (control diet), six (AURA diet), and seven (washout).

Since there were animal-specific differences in the abundances of rumen microbes and SCFAs, the microbial densities and SCFA concentrations in the experimental animals were normalized such that the mean of each parameter in all analyzed samples was the same for both animals. This allowed the Tukey's HSD post hoc test to indicate true shifts within each period of measurement rather than merely reflecting differences between the animals in their baseline levels of rumen microorganisms or SCFA concentrations.

All statistical tests on both ex vivo and in vivo data were conducted using the IBM SPSS Statistics Subscription (Build 1.0.0.1327) software package (Chicago, IL, USA).

\section{Results}

\subsection{Comparison of Fatty Acid Profiles in Different Lipid Sources}

Prior to introducing the different fatty acid sources (FO, AURA, and the EtOAc extract of AURA) to the rumen environment, their profiles were analyzed. These products are of specific interest because of their omega- 3 fatty acid, EPA, and DHA contents. With the analytical approach applied, we found that the contents of C12-C24 acids in FO and the AURA test product were $74 \%$ and $53 \%$, respectively. Thus, $47 \%$ of the AURA product consists of other components, such as carbohydrates, that can potentially affect rumen fermentation. Since one of the study objectives was to assess the relative effect of the pure fatty acid fraction, the AURA product was tested both as-is and after enrichment of the oil fraction through an EtOAc extraction. Figure 1 shows the fatty acid profiles for FO, the original AURA product, and the EtOAc extract of AURA. As can be seen, the FO fatty acid profile was very different from that of the AURA product. The proportions of C16:0 and DHA were much lower in FO, whereas the proportions of unsaturated C16, C18, and C20 acids and EPA were much higher in FO than in the AURA product. The AURA EtOAc extract had a nearly identical fatty acid profile to the original AURA product.

\subsection{Effect of Various Fatty Acid Sources on Rumen Fermentation Activity Ex Vivo-Experiment I}

Intact AURA product, the AURA EtOAc extract, and FO were introduced in increasing concentrations to the ex vivo rumen fermentation model. Overall rumen fermentation activity was measured as the efficiency of bacterial production of gaseous and acidic bacterial metabolic end products. The product concentrations in the fermentation medium ranged from 0 to $0.6 \mathrm{mg} / \mathrm{mL}$ of the original AURA product. The AURA extract and FO were dosed so that the total concentration of $\mathrm{C} 12-\mathrm{C} 24$ acids was the same as in the corresponding dose of the original AURA product. As shown in Table 3, none of the test products at any dose affected the fermentation activity of rumen microbes in the model used. The results were consistent when measured as either total gas production during fermentation or as the SCFA concentration after $8 \mathrm{~h}$ of fermentation (Table 3). Additionally, the profiles of individual acids were unaffected by the test products (Table S1; Supplementary Materials). 


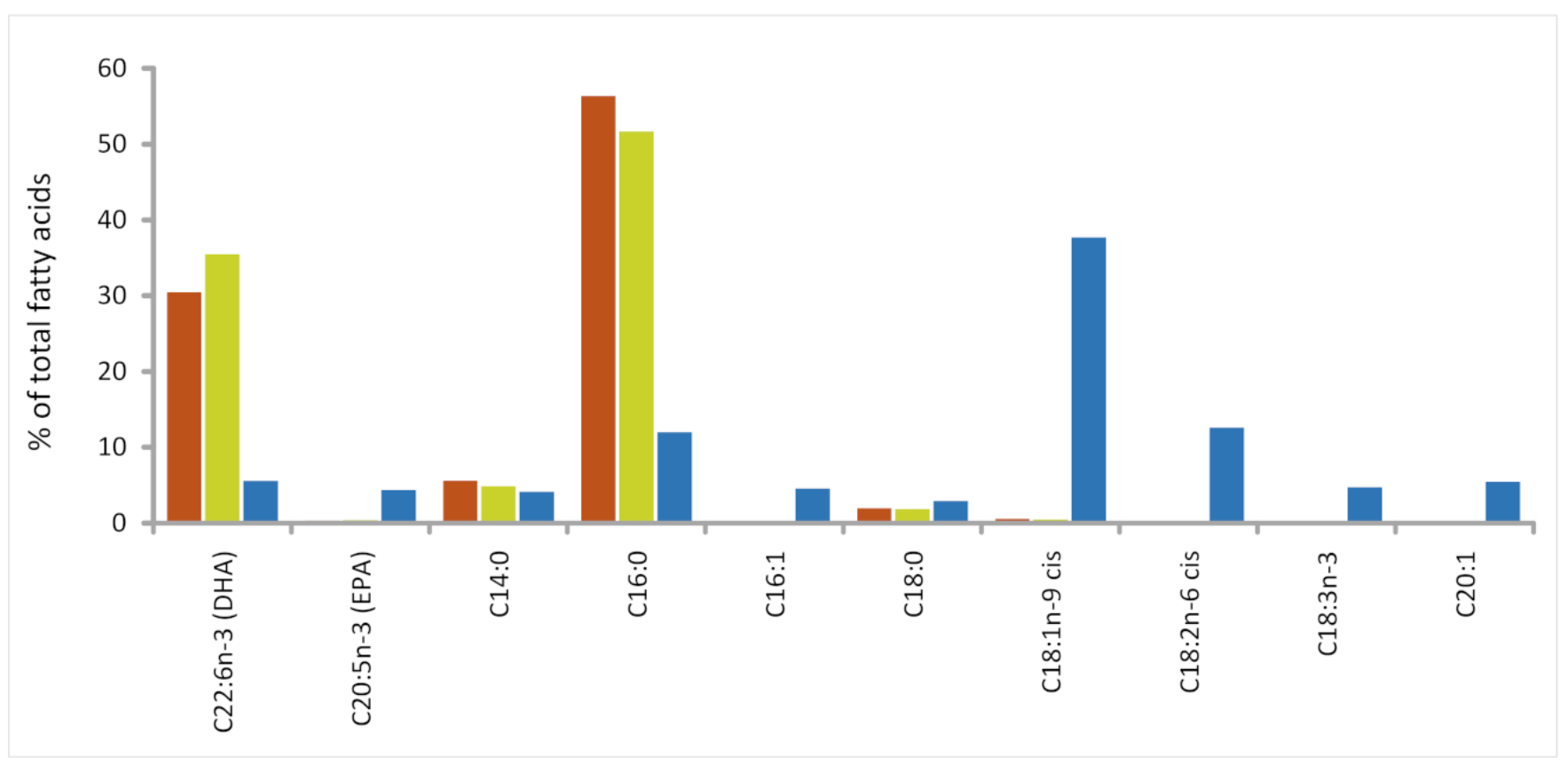

Figure 1. Profiles of the major fatty acids in the original Aurantiochytrium limacinum (AURA) product, the ethyl acetate extract of AURA, and food-grade fish oil (FO). Column height indicates percentage of the selected acid in total C12-C24 acids. Legend: $\square$ AURA; $\square$ AURA extract; $\square$ FO.

Table 3. Effect of different doses of Aurantiochytrium limacinum (AURA) product *, ethyl acetate extract of AURA, and fish oil (FO) ${ }^{\dagger}$ on rumen fermentation activity, measured as gas and total short-chain fatty acid (SCFA) production by rumen microorganisms ex vivo.

\begin{tabular}{cccc}
\hline \multirow{2}{*}{ Diet } & Gas Production $(\mathbf{m L})$ & \multicolumn{2}{c}{ SCFA Concentration (mM) } \\
\cline { 2 - 4 } & $\mathbf{0 - 8 ~ h}$ & $\mathbf{0 ~ h}$ & $\mathbf{8 ~ h}$ \\
\hline Control & 21.8 & 9.54 & 66.3 \\
AURA dose 1 & 21.2 & 9.40 & 64.8 \\
AURA dose 2 & 22.1 & 9.41 & 68.2 \\
AURA dose 3 & 21.5 & 9.34 & 64.6 \\
AURA dose 4 & 21.1 & 9.28 & 64.8 \\
AURA extract dose 1 (equiv.) & 21.6 & 9.09 & 65.9 \\
AURA extract dose 2 (equiv.) & 21.7 & 9.35 & 64.3 \\
AURA extract dose 3 (equiv.) & 21.7 & 9.29 & 67.2 \\
AURA extract dose 4 (equiv.) & 21.4 & 9.32 & 65.0 \\
Fish oil dose 1 (equiv.) & 22.6 & 9.31 & 67.3 \\
Fish oil dose 2 (equiv.) & 22.2 & 9.35 & 68.1 \\
Fish oil dose 3 (equiv.) & 22.0 & 9.28 & 68.3 \\
Fish oil dose 4 (equiv.) & 21.7 & 9.29 & 63.9 \\
SEM & 0.40 & 0.09 & 1.90 \\
$p$ value ANOVA & 0.554 & 0.345 & 0.758 \\
\hline
\end{tabular}

*AURA concentration in fermentation medium: Dose $1(0.08 \mathrm{mg} / \mathrm{mL})$, Dose $2(0.15 \mathrm{mg} / \mathrm{mL})$, Dose $3(0.30 \mathrm{mg} / \mathrm{mL})$ and Dose $4(0.60 \mathrm{mg} / \mathrm{mL}) .{ }^{+} \mathrm{FO}$ concentration in fermentation medium: Dose $1(0.05 \mathrm{mg} / \mathrm{mL})$, Dose 2 (0.11 mg/mL), Dose $3(0.22 \mathrm{mg} / \mathrm{mL})$, and Dose 4 (0.44 mg/mL).

\subsection{Resistance of the Major Fatty Acids to Attack by Rumen Bacteria Ex Vivo-Experiment I}

During rumen fermentation, some LCFAs in the AURA test product and in FO can be expected to be degraded or directly transformed by bacteria or because of the highly reduced conditions prevailing in the rumen. Therefore, the main characteristic fatty acids were analyzed at the beginning of the experiment and after $8 \mathrm{~h}$ of ex vivo fermentation. Figure 2A-D show the concentrations of palmitic acid (C16:0), oleic acid (C18:1 n-9 cis), EPA (20:5 n-3), and DHA (C22:6n-3), which were the main characteristic acids of the 
AURA product and FO (see Figure 1). The background concentration of palmitic acid originating from the feed and rumen fluid inoculum was $0.09 \mathrm{mg} / \mathrm{mL}$, and the palmitic acid concentration increased in a dose-dependent manner when AURA was added to the fermentation vessel, whereas the addition of FO had little or no effect (Figure 2A). The palmitic acid concentration declined marginally over the $8 \mathrm{~h}$ of fermentation compared to the start of the experiment, but this reduction was unaffected by the addition of the test products. The oleic acid background concentration at $0 \mathrm{~h}$ was $0.07 \mathrm{mg} / \mathrm{mL}$ and was unaffected by the addition of the AURA product (Figure 2B). However, its concentration increased in parallel with the increasing FO dose. During fermentation, a significant $(26 \%)$ drop in the concentration of oleic acid was observed in all treatments. The background concentration of EPA in the fermentation medium was negligible and unaffected by the addition of the AURA product (Figure 2C). The addition of FO significantly increased the concentration of EPA; however, the concentration was low- $0.009 \mathrm{mg} / \mathrm{mL}$ at $0 \mathrm{~h}$ with the highest FO dose tested. During the $8 \mathrm{~h}$ fermentation, the concentration of EPA in the FO-amended treatments decreased by $16-26 \%$ depending on the dose.

Similar to EPA, DHA was absent in the control vessels (Figure 2D). At the highest dose of the AURA product, the concentration of DHA increased to $0.08 \mathrm{mg} / \mathrm{mL}$. The concentration of DHA also increased with FO addition to $0.01 \mathrm{mg} / \mathrm{mL}$ at the highest dose. During the $8 \mathrm{~h}$ ex vivo rumen fermentation, the concentration of DHA declined by approximately $14 \%$ and $19 \%$ in the AURA and FO treatments, respectively.

\subsection{Tolerance of Rumen Bacteria to Extreme Doses of AURA Supplement Ex Vivo-Experiment II}

Experiment I showed that doses of the AURA product up to $0.6 \mathrm{mg} / \mathrm{mL}$ did not affect fermentation by rumen bacteria. Although $0.6 \mathrm{mg} / \mathrm{mL}$ exceeds the concentration of the product that could realistically be used in commercial practice, an additional study was conducted with even higher doses of up to $2.5 \mathrm{mg} / \mathrm{mL}$ ( $9.1 \%$ of feed dry matter). Again, the overall rate of fermentation was determined by measuring total bacterial gas production and SCFA concentrations. In addition, the effect of increasing concentrations of the AURA product on total rumen bacterial numbers during the $8 \mathrm{~h}$ of fermentation was assessed. Cumulative gas production measured at 4 and $8 \mathrm{~h}$ was completely unaffected by the AURA product in rumen fluid, even at the highest concentration $(2.5 \mathrm{mg} / \mathrm{mL})$ (Table 4). The initial concentration of total SCFAs, which originated from the $10 \%$ rumen fluid inoculum used, was $14.9 \mathrm{mM}$; during the $8 \mathrm{~h}$ of fermentation, the total SCFA concentration increased to $79.8 \mathrm{mM}$. The proportions of different dominant acids were not significantly affected by the test product, but a small numerical increase in propionic acid and a decrease in lactic acid were detected (Table S2; Supplementary Materials). The results also show that the inclusion of the AURA product, even at the highest tested concentrations, did not influence rumen bacterial numbers at any of the time points studied (Table 4). Thus, it can be concluded that the AURA product does not inhibit feed fermentation by rumen microbiota, even at extremely high product doses.

\subsection{Resistance of Docosahexaenoic Acid to Rumen Bacterial Attack Ex Vivo-Experiment II}

Since the primary objective of feeding algal products to ruminants is to enrich the DHA contents of consumer products of animal origin, the DHA concentration was analyzed when high concentrations of AURA were introduced under ex vivo rumen conditions. The results revealed a small reduction in the DHA concentration throughout the $8 \mathrm{~h}$ fermentation, especially at lower product doses (Figure 3). The observed dose-dependent numerical reductions in the DHA concentrations between 0 and $8 \mathrm{~h}$ were $0.7 \%$ (highest dose) to $21.4 \%$ (lowest dose), but the changes were not statistically significant for any of the applied doses at the confidence level of $p=0.05$ (Figure 3 ). Hence, the results obtained using high doses of AURA are in line with those observed for the lower doses of AURA (Experiment I, Figure 2D). 


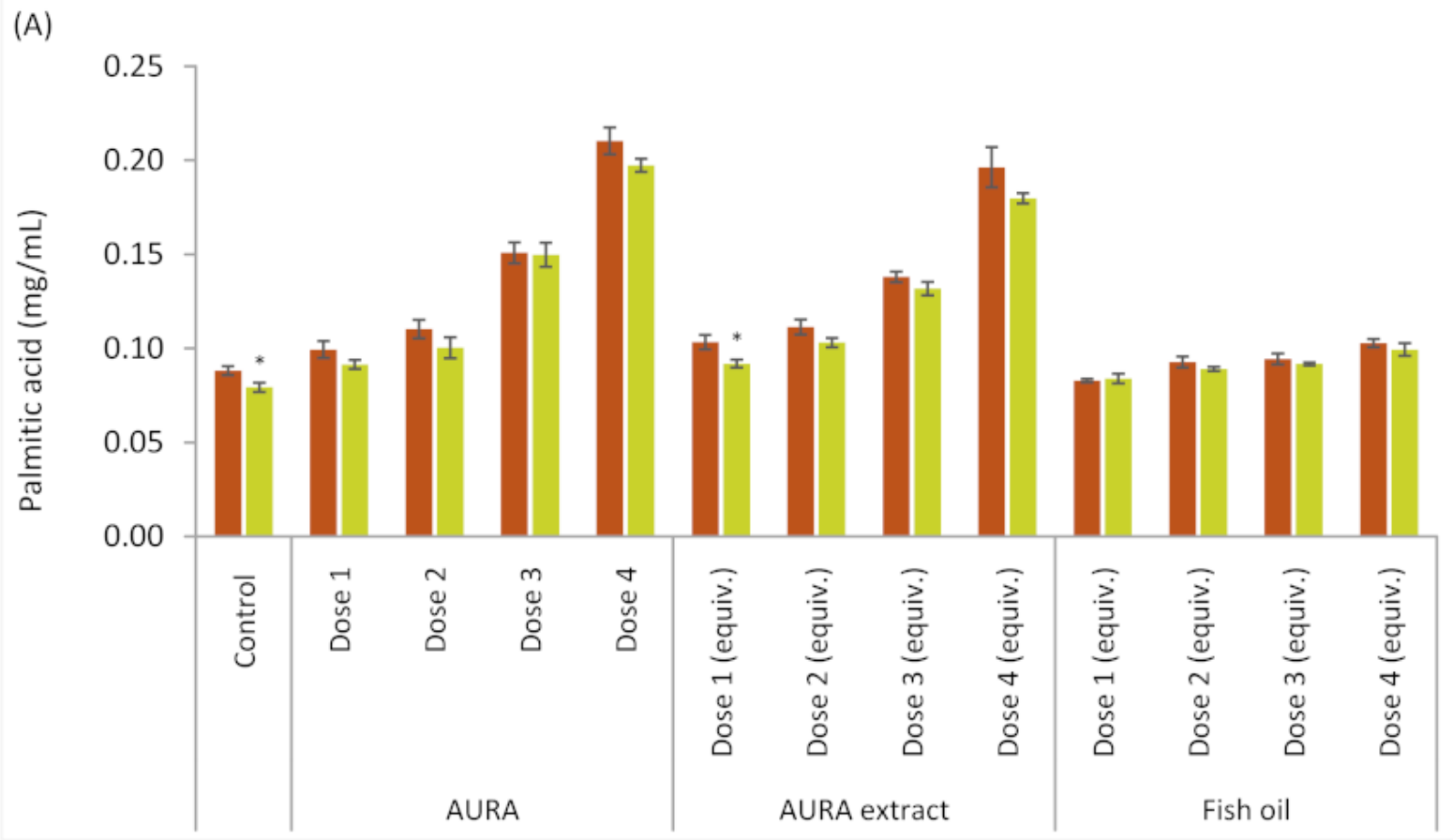

(B)

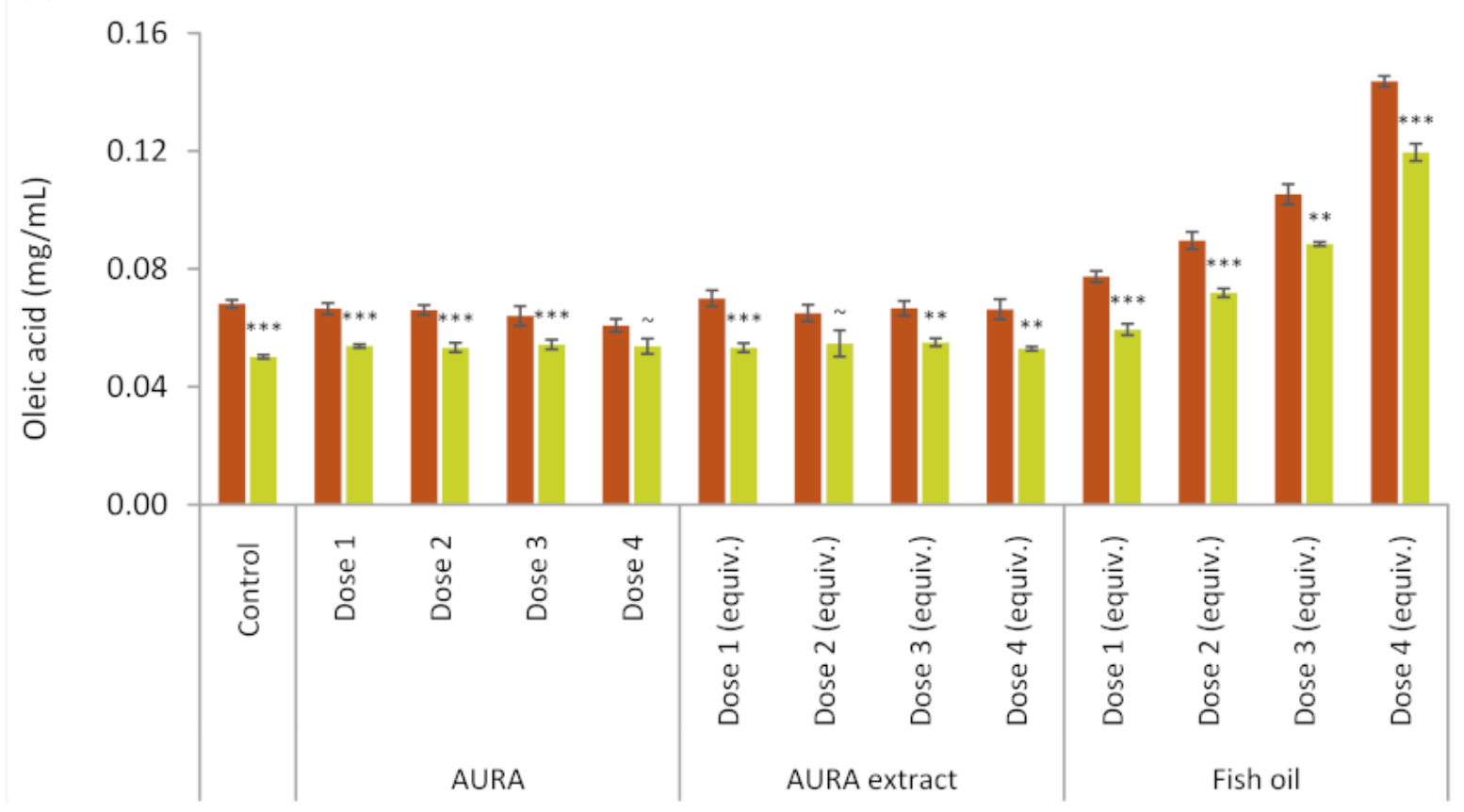

Figure 2. Cont. 
(C)

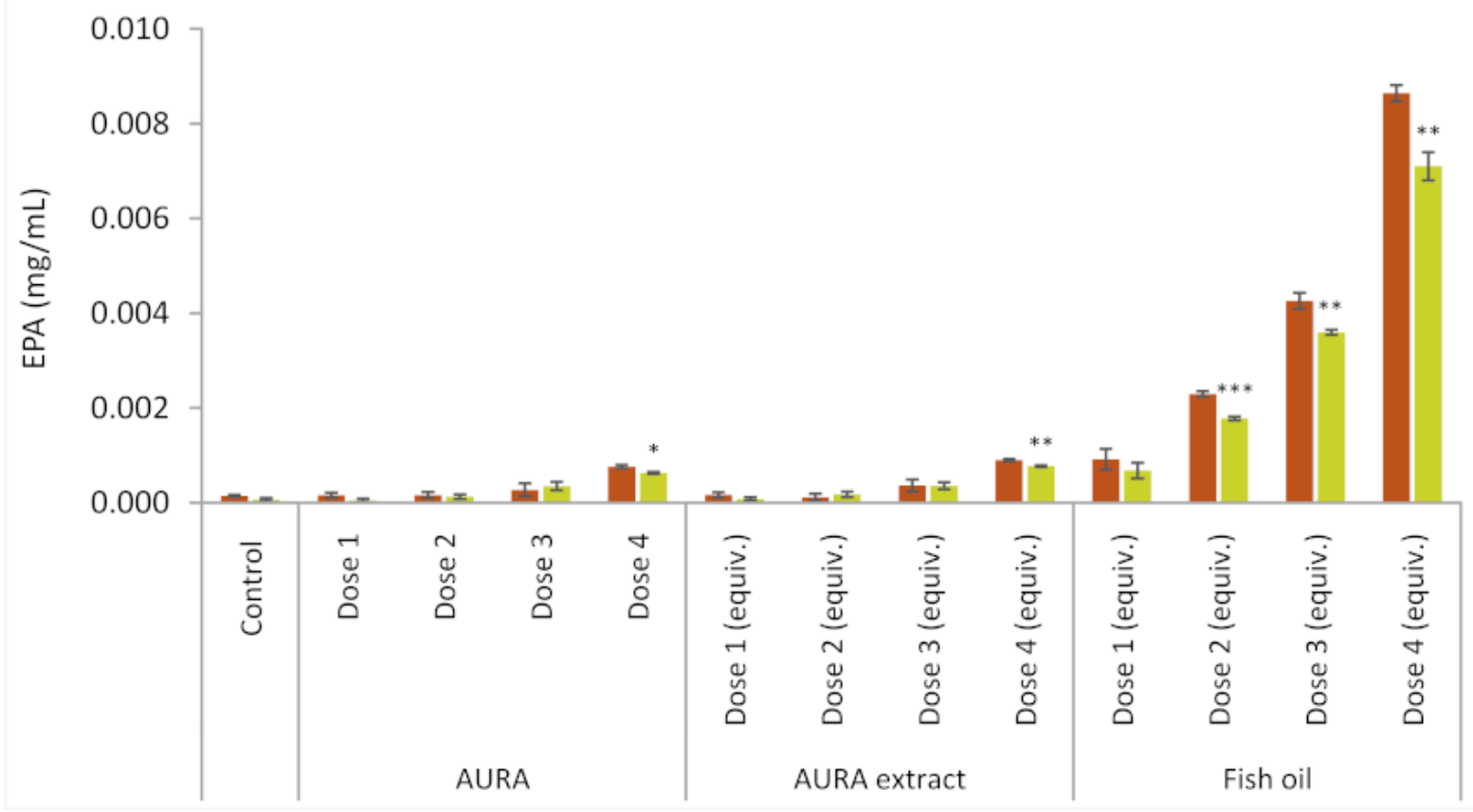

(D)

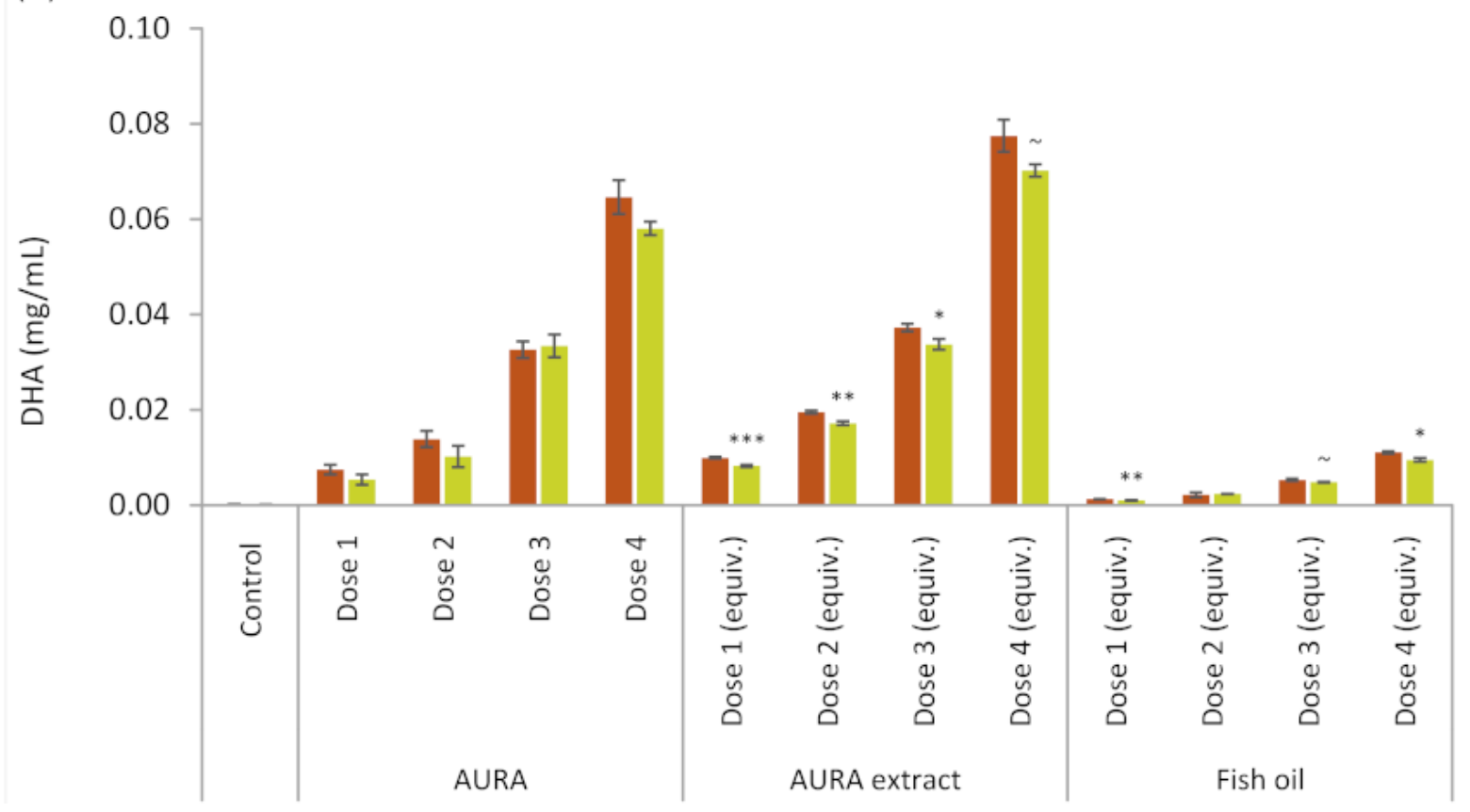

Figure 2. Stability of selected long-chain fatty acids during $8 \mathrm{~h}$ of rumen fermentation ex vivo with different doses of Aurantiochytrium limacinum (AURA) product, ethyl acetate extract of AURA, and fish oil (FO). Concentration of (A) palmitic acid; C16:0, (B) oleic acid; C18:1 n-9 cis, (C) EPA; 20:5 $n-3$, and (D) DHA; C22:6n-3. Control shows the background level of the acid with no test product addition. Error bars indicate standard error of the mean between five replicate fermentation vessels. Asterisks and tildes show the significance of the concentration change during the $8 \mathrm{~h}$ fermentation (between 0 and $8 \mathrm{~h}$, analyzed separately for each treatment by independent sample $t$-test; **** $p<0.001$; $\left.{ }^{* *} p<0.01 ; * p<0.05 ; \sim p<0.1\right)$. Legend: $\square$ acid concentration at $0 \mathrm{~h}$; $\square$ acid concentration at $8 \mathrm{~h}$. AURA concentration in fermentation medium: Dose $1(0.08 \mathrm{mg} / \mathrm{mL})$, Dose $2(0.15 \mathrm{mg} / \mathrm{mL})$, Dose 3 $(0.30 \mathrm{mg} / \mathrm{mL})$ and Dose $4(0.60 \mathrm{mg} / \mathrm{mL})$. FO doses in fermentation medium: Dose $1(0.05 \mathrm{mg} / \mathrm{mL})$, Dose $2(0.11 \mathrm{mg} / \mathrm{mL})$, Dose $3(0.22 \mathrm{mg} / \mathrm{mL})$ and Dose $4(0.44 \mathrm{mg} / \mathrm{mL})$. 
Table 4. Effect of extreme doses of Aurantiochytrium limacinum (AURA) product * on rumen fermentation activity, measured as gas and total short-chain fatty acid (SCFA) production by rumen microorganisms and total microbial density ex vivo.

\begin{tabular}{|c|c|c|c|c|c|c|c|c|}
\hline \multirow{2}{*}{ Diet } & \multicolumn{2}{|c|}{ Gas Production $(\mathrm{mL})$} & \multicolumn{3}{|c|}{ SCFA Concentration $(\mathrm{mM})$} & \multicolumn{3}{|c|}{ Total Bacteria( $\log _{10} 16 \mathrm{~S}$ rDNA Copies/mL) } \\
\hline & $0-4 \mathrm{~h}$ & $0-8 \mathrm{~h}$ & $\mathbf{0 ~ h}$ & $4 \mathrm{~h}$ & $8 \mathrm{~h}$ & $\mathbf{0 ~ h}$ & $4 \mathrm{~h}$ & $8 \mathrm{~h}$ \\
\hline Control & 10.2 & 23.4 & 14.9 & 48.7 & 79.8 & 10.0 & 10.8 & 11.2 \\
\hline $\begin{array}{l}\text { AURA } \\
\text { dose } 1\end{array}$ & 10.3 & 23.5 & 14.9 & 49.8 & 78.7 & 10.0 & 11.1 & 11.1 \\
\hline $\begin{array}{l}\text { AURA } \\
\text { dose } 2\end{array}$ & 9.9 & 23.7 & 15.0 & 47.7 & 78.8 & 9.8 & 11.0 & 11.4 \\
\hline $\begin{array}{l}\text { AURA } \\
\text { dose } 3\end{array}$ & 10.5 & 22.7 & 14.6 & 51.1 & 78.3 & 10.0 & 11.0 & 11.1 \\
\hline $\begin{array}{l}\text { AURA } \\
\text { dose } 4\end{array}$ & 10.5 & 23.7 & 15.3 & 49.8 & 82.5 & 10.1 & 10.9 & 11.3 \\
\hline SEM & 0.27 & 0.44 & 0.20 & 1.41 & 2.04 & 0.012 & 0.012 & 0.017 \\
\hline $\begin{array}{c}p \text { value } \\
\text { ANOVA }\end{array}$ & 0.659 & 0.480 & 0.242 & 0.547 & 0.636 & 0.590 & 0.166 & 0.270 \\
\hline
\end{tabular}

* AURA concentrations in fermentation medium: Dose $1(0.25 \mathrm{mg} / \mathrm{mL})$, Dose $2(0.63 \mathrm{mg} / \mathrm{mL})$, Dose 3 $(1.50 \mathrm{mg} / \mathrm{mL})$, and Dose $4(2.50 \mathrm{mg} / \mathrm{mL})$.

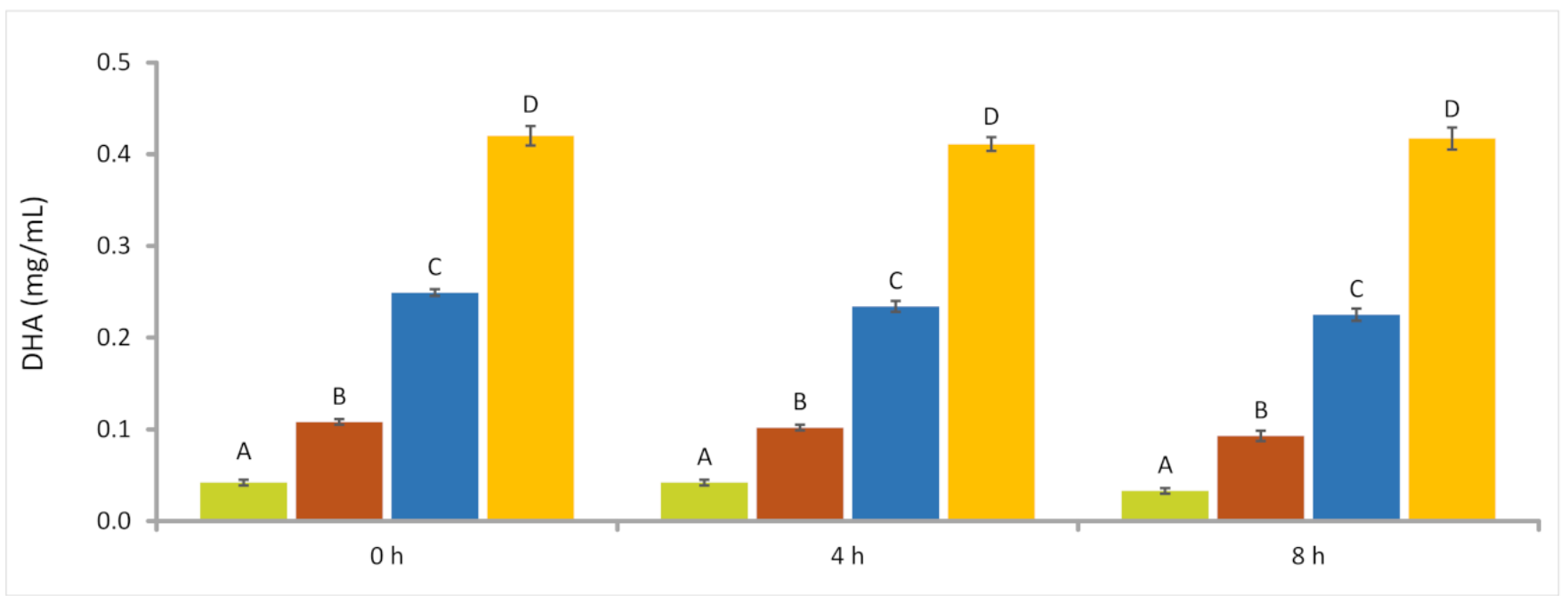

Figure 3. Resistance of docosahexaenoic acid (DHA) to rumen microbial attack at 0,4 , and $8 \mathrm{~h}$ of ex vivo fermentation. Error bars indicate standard error of the mean for five replicate fermentation vessels. Different letters above bars representing each product dose and timepoint indicate significant differences in the DHA concentration according to Tukey's post hoc test with $\alpha=0.05$. Legend: AURA $0.25 \mathrm{mg} / \mathrm{mL}$; AURA $0.63 \mathrm{mg} / \mathrm{mL}$; AURA $1.50 \mathrm{mg} / \mathrm{mL}$; AURA $2.50 \mathrm{mg} / \mathrm{mL}$.

\subsection{Effect of the AURA Product on LCFA Content in Dairy Cow Milk}

The resistance of DHA to degradation during rumen fermentation is a prerequisite for its deposition in dairy cow milk. Since high resistance was achieved in laboratory fermentation, the next step was to confirm DHA deposition in the milk of lactating dairy cows. This was performed in a seven-week in vivo trial with two dairy cows. Milk was collected for analysis of LCFA and DHA contents on the two consecutive days of both weeks of the two-week control diet period. The procedure was repeated each week of the four-week AURA diet period and again after the one-week washout period (original control diet). The concentration of total LCFAs was slightly elevated in the milk of both experimental cows during the AURA diet period, but in milk collected after the one-week washout period, no change in the total LCFA concentration was detected (Figure 4A). Regarding DHA, the concentration in milk was negligible when the cows were on the 
control diet. However, at the end of the final week of the AURA diet, a considerable 25-fold increase in the DHA concentration was observed, with the average of the two cows being $59.1 \mu \mathrm{g} / \mathrm{mL}$. After the one-week washout phase on the control diet, a 36\% reduction in the concentration of DHA in milk was detected (Figure 4B). Interestingly, one month after the AURA diet period ended, the average concentration of DHA in milk was still $24.1 \mu \mathrm{g} / \mathrm{mL}$ (data not shown). This suggests that, during the four-week AURA diet period, a significant deposition of DHA occurred in animal tissues, and this fat-soluble acid was then gradually released into the milk.
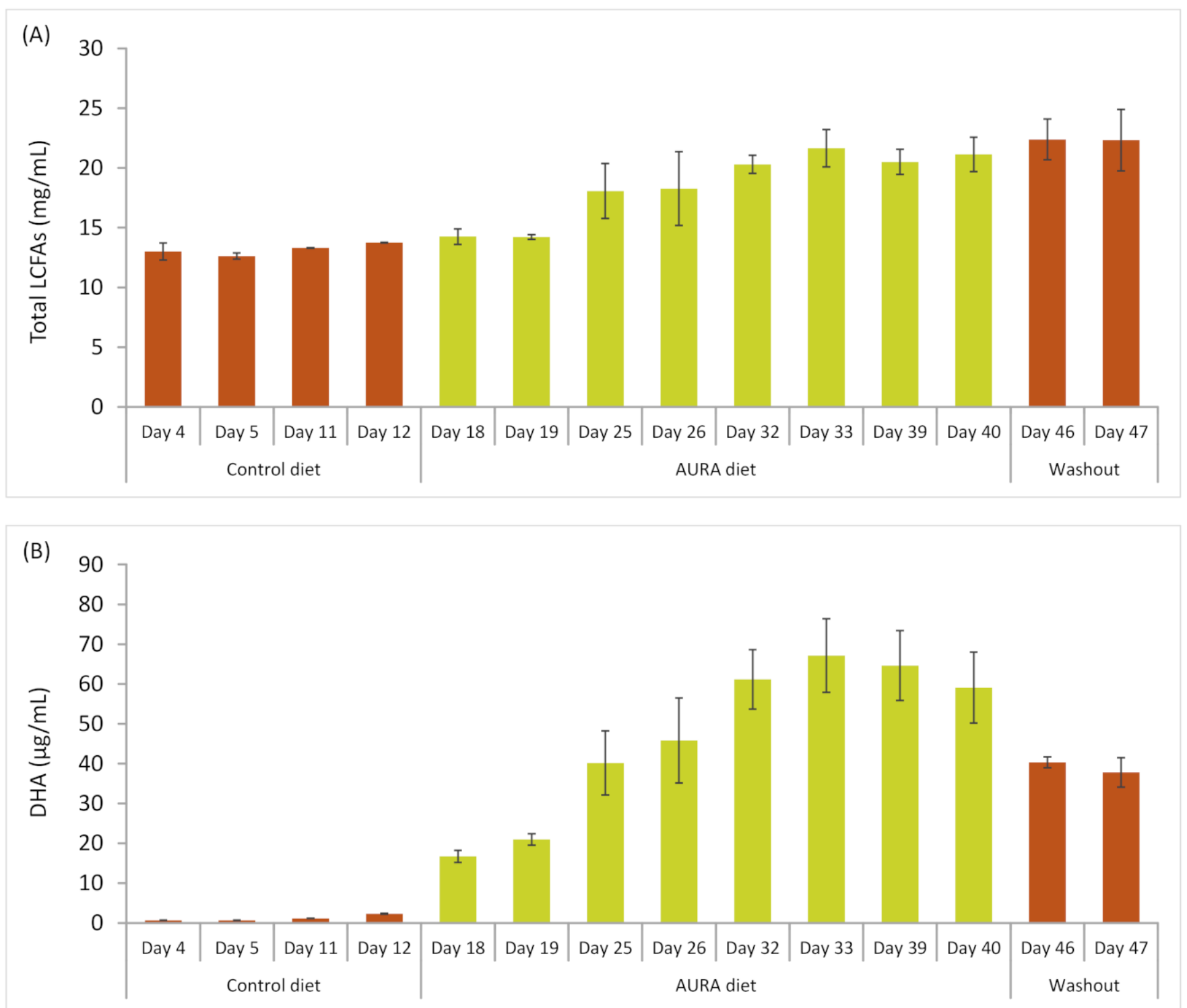

Figure 4. Average concentrations of (A) total long-chain fatty acids (LCFAs) and (B) docosahexaenoic acid (DHA) in the milk of two cows from two consecutive days in each diet period week (control, Aurantiochytrium limacinum (AURA), washout). Error bars indicate standard error of the mean for two cows.

\subsection{Effect of the AURA Product on Rumen Microbiota and Metabolism in Cannulated Dairy Cows}

The use of rumen-cannulated dairy cows in the trial enabled the sampling of rumen fluid on four consecutive days at the end of each feeding period for the analysis of selected rumen bacteria, archaea, and protozoa as well as residual concentrations of VFA and lactic acid. A significant change was observed in the rumen lactobacilli, with the number of Lactobacillus spp. decreased by $66 \%$ when the AURA diet was supplied for 3-4 weeks. 
When the feed was changed back to the control diet (washout), the number of lactobacilli increased again (Table 5). For the lactate-utilizing species Megasphaera elsdenii, a significant $80 \%$ reduction in abundance was detected at the end of the AURA diet period. The number of methanogens was significantly lower during the AURA diet period, with an observed reduction of $59 \%$ compared with that of the control diet. When the diet was switched back to control (washout) for one week, the methanogen numbers returned to their original level (Table 5). All other rumen microbes that we quantified in the in vivo study were unaffected by dietary changes.

Table 5. Effect of dietary Aurantiochytrium limacinum (AURA) on rumen microbiota and microbial metabolites in vivo.

\begin{tabular}{|c|c|c|c|c|c|}
\hline Parameter & Control Diet ${ }^{a}$ & AURA Diet $^{\text {a }}$ & Washout $^{\text {a }}$ & SEM & $p$ Value ANOVA \\
\hline Total eubacteria $\left(\log _{10}\right.$ gene copies $\left./ \mathrm{mL}\right)$ & 10.85 & 10.66 & 10.86 & 0.08 & 0.172 \\
\hline Methanogens $\left(\log _{10}\right.$ gene copies $\left./ \mathrm{mL}\right)$ & $9.84^{\mathrm{A}}$ & $9.46^{\mathrm{B}}$ & $9.62 \mathrm{AB}$ & 0.10 & 0.055 \\
\hline Bacteroides-Prevotella $\left(\log _{10}\right.$ gene copies/mL) & 10.31 & 10.28 & 10.49 & 0.09 & 0.221 \\
\hline Ruminococcaceae $\left(\log _{10}\right.$ gene copies $\left./ \mathrm{mL}\right)$ & 9.38 & 9.25 & 9.47 & 0.10 & 0.299 \\
\hline Lachnospiraceae ( $\log _{10}$ gene copies /mL) & 10.07 & 9.88 & 10.11 & 0.12 & 0.437 \\
\hline S. ruminantium ( $\log _{10}$ gene copies $\left./ \mathrm{mL}\right)$ & 8.41 & 8.40 & 8.67 & 0.09 & 0.150 \\
\hline Lactobacillus spp. $\left(\log _{10}\right.$ gene copies/mL) & $8.30^{\mathrm{A}}$ & $7.83^{\mathrm{B}}$ & $8.28^{\mathrm{A}}$ & 0.10 & 0.007 \\
\hline Streptococcus spp. (log 10 gene copies $/ \mathrm{mL})$ & 8.61 & 8.43 & 8.57 & 0.12 & 0.600 \\
\hline F. succinogenes $\left(\log _{10}\right.$ gene copies $\left./ \mathrm{mL}\right)$ & 6.90 & 7.24 & 7.33 & 0.13 & 0.074 \\
\hline M. elsdenii $\left(\log _{10}\right.$ gene copies $\left./ \mathrm{mL}\right)$ & $5.88^{\mathrm{A}}$ & $5.17^{\mathrm{B}}$ & $5.33^{\mathrm{B}}$ & 0.11 & 0.002 \\
\hline Veillonella spp. $\left(\log _{10}\right.$ gene copies $\left./ \mathrm{mL}\right)$ & 5.94 & 5.82 & 5.92 & 0.10 & 0.662 \\
\hline Total protozoa (log 10 gene copies $/ \mathrm{mL}$ ) & 8.43 & 8.21 & 8.45 & 0.15 & 0.548 \\
\hline Total SCFAs $(\mathrm{mM})$ & $113.03^{\mathrm{A}}$ & $103.68^{\mathrm{B}}$ & $107.79^{C}$ & 0.99 & 0.000 \\
\hline Acetic acid (mM) & $70.75^{\mathrm{A}}$ & $66.00^{\mathrm{B}}$ & $69.07^{\mathrm{A}}$ & 0.54 & 0.000 \\
\hline Propionic acid (mM) & $17.99 \mathrm{~A}$ & $15.73^{\mathrm{B}}$ & $15.55^{\mathrm{B}}$ & 0.30 & 0.000 \\
\hline Butyric acid (mM) & $14.90^{\mathrm{A}}$ & $13.94^{\mathrm{B}}$ & $14.53^{\mathrm{AB}}$ & 0.21 & 0.022 \\
\hline Lactic acid (mM) & $3.57^{\mathrm{A}}$ & $2.36^{\mathrm{B}}$ & $3.18^{\mathrm{A}}$ & 0.21 & 0.005 \\
\hline
\end{tabular}

${ }^{a}$ Upper case letters denote significant changes in microbial numbers among the different feeding phases as assessed by Tukey's post hoc test at risk level $\alpha=0.05$.

The residual concentrations of VFAs indicate an equilibrium between the acid production by microbes and the acid uptake by the rumen epithelium. The results show that concentrations of individual VFA were generally reduced during the AURA diet period by $6.7 \%, 12.6 \%$, and $6.4 \%$ for acetic, propionic, and butyric acids, respectively, compared with the control diet (Table 5). The residual concentration of lactic acid, a common transient intermediate of carbohydrate fermentation with rumen bacteria, was also significantly reduced (by 34\%) under the AURA diet (Table 5). As with the rumen Lactobacillus spp. numbers, the lactic acid concentration also increased when the feed was changed back to the control diet (washout).

\section{Discussion}

Previous studies have examined the effects of LC-PUFAs on rumen fermentation and production parameters $[8,36,37]$. Pure acids have been tested in some studies, whereas in others, complex acid sources composed of mixtures of acids have been used [8,38-42]. The results of these studies have been inconsistent, partly because of the different experimental models used and partly because of the different test product compositions and doses applied. It is indisputable that the replacement of saturated fats in animal products with LC-PUFAs would be beneficial for the health of human end-consumers. However, in commercial practice, this concept will only be viable if there is no negative effect on productivity and if the LC-PUFA supplement is reasonably priced. Practical application will also be nonviable if strong inhibition of total rumen fermentation activity (VFA production) occurs, or if microbial fermentation shifts in an unfavorable direction and can no longer support body weight gain or the production of high volumes of milk of the correct 
composition. In this study, we conducted a detailed investigation of one potential protist source of healthy fatty acids at realistic doses. The use of high product doses would not be meaningful because excess LC-PUFA is very well known to inhibit bacterial fermentation and because the benefits gained in product quality could not compensate for the higher price of high doses.

There are many possible variations of the laboratory rumen fermentation experiment. Laboratory arrangements are always models and therefore intended to mimic conditions and the fermentation activity in the rumen with sufficient accuracy for considering the questions at hand. In the model used in this study, special attention was paid to proper physicochemical conditions, the careful handling of inoculum, and precise execution of the fermentation, sampling, and analysis of the vessels. The five fermentation vessels with independently introduced feed components, test products, and inoculum were considered as replicates in the statistical evaluation. The experimental arrangement allows accurately determining the response of the specific rumen microbiota introduced in the vessels to the test products used. The question remains whether the rumen content used has a microbiota composition that adequately represents the microbiota of the whole herd of the farm, all farms in a specific country, or all countries with different feeding regimens. Although the magnitude of test product effects could vary, there are no reports suggesting that the existence and direction of fermentation effects would be different in individual animals on a given diet. In the two ex vivo experiments, we used rumen fluid inoculum from two different dairy cows with identical results. It remains to be shown whether similar results are obtained, for example, with American beef cattle fed with a high-grain diet.

In the studies described here, the concentration of the AURA test product ranged from 0.08 to $2.5 \mathrm{mg} / \mathrm{mL}$, supplying $0.04-1.3 \mathrm{mg} / \mathrm{mL}$ of total fatty acids or $0.013-0.40 \mathrm{mg} / \mathrm{mL}$ of DHA. The dose of AURA applied in the feeding experiment with dairy cows was $140 \mathrm{~g} /$ head/day, which was administered in four servings during the day. Assuming a rumen volume of $60 \mathrm{~L}$ [43], the introduced dose corresponds to $0.93 \mathrm{mg} / \mathrm{mL}$, which is within the concentration range tested in the ex vivo models. Two independent fermentation experiments confirmed that none of the AURA doses tested affected rumen fermentation in any way, with no changes detected in either gas or SCFA production nor in total eubacteria abundance. A recent study investigating the potential antimicrobial effects of AURA on nine pure cultures of intestinal bacteria related to human health showed that the product did not inhibit bacterial growth at $10 \mathrm{mg} / \mathrm{mL}$ [44], which is four times the highest concentration used in this study. On the other hand, studies of the pure cultures of rumen bacteria involved in the biohydrogenation of LC-PUFAs (Butyrivibrio fibrisolvens and $B$. proteoclasticus) have shown that $>30 \mu \mathrm{g} / \mathrm{mL}$ of various pure unsaturated fatty acids can inhibit growth $[45,46]$. In vitro studies using complex rumen microbiota as an inoculum and ruminant feed as a substrate have not observed inhibition of rumen fermentation in cows. For example, a batch fermentation study found that neither pure EPA nor DHA at $0.2 \mathrm{mg} / \mathrm{mL}$ ( $2 \%$ of feed DM) had any significant effect on microbial gas or VFA production, or the on the levels of feed DM [47]. A study examining sunflower, fish, and algae oils in a RUSITEC continuous fermentation system showed that all oil combinations at $2-3 \%$ of feed DM suppressed methane production but increased total VFA and propionate [48].

Previous tests on various LC-PUFAs have produced inconsistent results; therefore, the benefits of feed supplements containing healthy unsaturated fatty acids have been questioned. There are several reasons for these apparent contradictions in the published literature. One is that the effective concentration of LC-PUFAs to which the bacteria are exposed in the test system may not be the same as the introduced dose for a given volume of culture or rumen contents. It is worth noting that in studies with pure bacterial cultures and liquid growth medium, the lipophilic compounds tend to be enriched in biological membranes and, consequently, the density of bacteria in solution can play a significant role. A dense microbial system tolerates higher product concentrations because the effective product dose per bacterium is lower. This implies that the microbial community in the true rumen would tolerate higher LC-PUFA concentrations than that in any laboratory 
fermentation model. Another important element is the presence of a solid feed matrix, which can be expected to protect bacteria by binding some potentially inhibitory compounds in a reversible fashion, as observed in other biological systems [49]. Typically, a solid matrix is absent in studies with pure bacterial cultures, while it is commonly included when complex microbial communities are used as the inoculum in batch or continuous fermentation models. When a solid matrix is present, it is worth considering whether the concentration of the test product should be calculated against the feed DM content or the culture volume. It is difficult to judge which is the correct approach, but it is important to acknowledge that this may have a major impact on the tolerance of rumen bacteria to LC-PUFA compounds. In the ex vivo arrangement used in the experiments described in this paper, the highest concentration of AURA product was $2.5 \mathrm{mg} / \mathrm{mL}$ when calculated against the liquid volume (corresponding to $1.3 \mathrm{mg} / \mathrm{mL}$ of total fatty acids or $0.4 \mathrm{mg} / \mathrm{mL}$ of DHA), but it comprised $9.1 \%$ when calculated as a percentage of feed DM. When the effect of a product on microbial fermentation is sought, it is necessary to consider the effective concentration of the product that the bacteria will encounter. The effective concentration is heavily influenced by the water solubility of the product and the presence of a solid matrix to which part of or the entire product may potentially attach.

Previous in vivo feeding studies have mainly concentrated on fatty acid biohydrogenation, potential shifts in rumen microbial community structure, and the physiology of the animal, but not on parameters connected to overall fermentation activity. Algal biomass at $1 \%$ and $\mathrm{FO}$ at $2-3 \%$ of feed DM have been found to inhibit biohydrogenation and affect the abundance of bacteria responsible for biohydrogenation $[39,50]$. Furthermore, DHArich algal biomass provided at $100 \mathrm{~g} / \mathrm{head} /$ day has been found to improve reproductive performance in dairy cows, an additional health benefit of feeding with fatty acids [51]. In the in vivo experiment in the present study, the residual concentration of total SCFAs was slightly reduced during the four weeks of the AURA diet. However, all the available facts suggest that this reduction was not due to the suppression of rumen fermentation but is most likely attributable to the improved efficiency of VFA uptake through the rumen epithelium when LC-PUFAs are present in the diet. This proposal is supported by the following facts based on our study: (1) the calculated LC-PUFA concentration in the rumen was less than half the actual concentration, showing that there was no inhibition in the ex vivo experiments; (2) the actual LC-PUFA concentration in the rumen is likely to be lower than that calculated, since the acids are continuously absorbed; (3) the density of bacteria and the feed DM content were significantly higher in the rumen than in the ex vivo experiments, thus protecting the bacteria in the rumen environment from potentially inhibitory LC-PUFAs; and (4) the total density of bacteria in the rumen was not reduced upon exposure to the AURA product.

Multiple studies have shown that LC-PUFA-containing products alter the composition of rumen microbiota, since different microorganisms react differently to the presence of PUFAs in the growth habitat $[39,48,50,52]$. Some microbial changes were observed in the in vivo experiment in this study. The most significant finding was related to bacteria involved in lactic acid metabolism pathways. At the end of the four-week AURA diet period, growth of a major lactic acid-producing genus, Lactobacillus spp., was significantly suppressed, as was that of representatives of the genus Megasphaera, which is known to be involved in rumen lactic acid utilization $[53,54]$. Moreover, the residual concentration of lactic acid in rumen fluid was significantly decreased. This may indicate that the risk of lactic acidosis is reduced when the AURA product is used in dairy cow diets, but further studies are needed to reveal the detailed mode of action. Interestingly, the density of methanogens was also lower at the end of the AURA diet period. There were similar findings in a previous study when various oils rich in unsaturated fatty acids were introduced into the rumen system [48,55-57]. In the present study, microbial alterations occurred when AURA was added to the diet, but these began to revert after the AURA product was removed from the diet. This indicates that the observed changes were not a 
result of temporal effects related to the season or phase of lactation but were truly associated with the introduction and withdrawal of the AURA test product in the diet.

Although understanding the effects of an LC-PUFA dietary supplement on rumen microbial activity is essential for its commercial adoption, it is equally important to demonstrate that the essential omega- 3 fatty acids survive the complex rumen ecosystem and are deposited in the milk and meat. In our ex vivo experiments that included the AURA product, the disappearance of the C22 fatty acid DHA was concentration-dependent; the higher the concentration of introduced AURA, the smaller the proportion of DHA that disappeared during fermentation. At levels corresponding to the dose recommended for commercial production animals, approximately $10 \%$ of the DHA was degraded or transformed by rumen microorganisms. For EPA, a characteristic $\mathrm{C} 20$ fatty acid in FO, the reduction during fermentation was nearly $20 \%$. One type of transformation is biohydrogenation catalyzed by anaerobic rumen bacteria that use unsaturated fatty acids as ultimate electron acceptors in their electron transport chains. It is worth noting that LCFAs do not disappear solely due to biohydrogenation but are also used as building blocks in bacterial anabolism. In this study, almost $10 \%$ of the fully saturated palmitic acid, which cannot be used as an electron acceptor, disappeared during fermentation. Ruminal polyunsaturated C18 fatty acids have been widely studied, and the active role of the rumen bacteria, especially that of Butyrivibrio species, in the partial or complete ruminal biohydrogenation of C18 has been confirmed $[39,48,50,58]$. It appears that the complete reduction of the carbon double bonds is a synergistic process that involves a consortium of bacteria, each with a specific role. Consequently, differences in these species' susceptibility to LC-PUFAs may lead to the accumulation of intermediates at certain acid concentrations. In general, the fatty acids with the longest carbon skeletons (EPA and DHA) are more resistant to biohydrogenation than shorter-chain PUFAs, such as linoleic and $\alpha$-linolenic acid [45,58]. DHA and EPA have also been reported to inhibit the hydrogenation of unsaturated C18 acids [47]. Based on these findings, it is unlikely that the DHA in AURA or the EPA in FO would be degraded in the rumen to an extent that would impair the deposition of in-feed DHA or EPA in edible products.

A pilot study conducted with two rumen-cannulated dairy cows confirmed that the introduction of the AURA product into the diet led to a clear change in the fatty acid profile in milk. The DHA concentration in milk increased over 25-fold during the four-week AURA diet period and then decreased by $30-40 \%$ within one week of washout. Interestingly, DHA was deposited in fat tissues during the four weeks of the AURA diet and then slowly released into milk during the subsequent week on the control (washout) diet. The effects of feeding with A. limacinum biomass on the milk production and composition have been previously reported $[9,24,51]$. Similar increases in DHA deposition in milk were found in these studies, but the total milk fat depression results were inconsistent. On the other hand, the total milk yield and yields of protein and lactose were significantly increased when the DHA-rich AURA product was added to the diet.

To summarize, this study shows that the addition of AURA, a product comprising DHA-rich microbial biomass, to the diet of dairy cows had no negative effects on rumen fermentation intensity and showed some positive effects on rumen microbial composition. DHA, the most important omega-3 fatty acid in AURA, was demonstrated to be stable and only underwent modest degradation in the rumen system, resulting in the successful deposition of DHA in the milk of cows that had been fed a diet supplemented with AURA.

Supplementary Materials: The following are available online at https:/ / www.mdpi.com/article/10 .3390/applmicrobiol2010004/s1. Table S1. Effect of different doses of Aurantiochytrium limacinum (AURA) product, ethyl acetate extract of AURA, and fish oil on short-chain fatty acid (SCFA) production by rumen microorganisms ex vivo. Table S2. Effect of extreme doses of Aurantiochytrium limacinum (AURA) product on on short-chain fatty acid (SCFA) production by rumen microorganisms ex vivo. 
Author Contributions: Conceptualization, T.R., J.A. and C.A.M.; Methodology, T.R. and J.A.; Formal Analysis, T.R.; Investigation, T.R.; Resources, J.A.; Data Curation, T.R.; Writing-Original Draft Preparation, T.R.; Writing-Review \& Editing, T.R., J.A. and C.A.M.; Supervision, J.A. and C.A.M.; Project Administration, C.A.M.; Funding Acquisition, C.A.M. All authors have read and agreed to the published version of the manuscript.

Funding: The work was financially supported by Alltech SARL (Vire, France).

Institutional Review Board Statement: The rumen-cannulated animals used as a source of rumen fluid and in the in vivo trial were maintained on a commercial research farm collaborating with Alimetrics Ltd. in Southern Finland, in accordance with European Union (EU) Directive 2010/63/EU on the protection of animals used for experimental or other scientific purposes. Cannulation and trial were approved by the Animal Experiment Board in Finland (ESAVI-2010-03430/Ym-23).

Informed Consent Statement: Not applicable.

Data Availability Statement: Data will be provided upon request.

Acknowledgments: The authors thank Osmo Siikanen and Rea Kankare for their professional work with rumen-cannulated cows and skilled laboratory techniques. Alltech Inc. (Nicholasville, KY) provided the AURA biomass for the studies.

Conflicts of Interest: The authors declare no conflicts of interest.

\section{Abbreviations}

$\begin{array}{ll}\text { ANOVA } & \text { Analysis of variance } \\ \text { AURA } & \begin{array}{l}\text { Aurantiochytrium limacinum } \\ \text { cardiovascular disease } \\ \text { CDV }\end{array} \\ \text { DHA } & \begin{array}{l}\text { docosahexaenoic acid } \\ \text { dry matter } \\ \text { DM }\end{array} \\ \text { EDTA } & \text { ethylenediaminetetraacetic acid } \\ \text { EPA } & \text { eicosapentaenoic acid } \\ \text { EtOAc } & \text { ethyl acetate } \\ \text { FM } & \text { fish meal } \\ \text { FO } & \text { fish oil } \\ \text { HSD } & \text { honestly significant difference } \\ \text { LCFA } & \text { long-chain fatty acid } \\ \text { LC-PUFA } & \text { long-chain omega-3 polyunsaturated fatty acid } \\ \text { SCFA } & \text { short-chain fatty acid } \\ \text { VFA } & \text { volatile fatty acid }\end{array}$

\section{References}

1. Feskens, E.J.M.; Sluik, D.; Van Woudenbergh, G.J. Meat Consumption, Diabetes, and Its Complications. Curr. Diabetes Rep. 2013, 13, 298-306. [CrossRef]

2. Sacks, F.M.; Lichtenstein, A.H.; Wu, J.; Appel, L.J.; Creager, M.A.; Kris-Etherton, P.; Miller, M.; Rimm, E.B.; Rudel, L.L.; Robinson, J.G.; et al. Dietary Fats and Cardiovascular Disease: A Presidential Advisory From the American Heart Association. Circulation 2017, 136, e1-e23. [CrossRef]

3. Ruan, Y.; Tang, J.; Guo, X.; Li, K.; Li, D. Dietary Fat Intake and Risk of Alzheimer's Disease and Dementia: A Meta-Analysis of Cohort Studies. Curr. Alzheimer Res. 2018, 15, 869-876. [CrossRef]

4. Willett, W.; Rockström, J.; Loken, B.; Springmann, M.; Lang, T.; Vermeulen, S.; Garnett, T.; Tilman, D. Food in the Anthropo-cene: The EAT-Lancet Commission on healthy diets from sustainable food systems. Lancet 2019, 393, 447-492. [CrossRef]

5. Hu, F.B.; Stampfer, M.J.; Manson, J.E.; Ascherio, A.; Colditz, G.; Speizer, F.E.; Hennekens, C.H.; Willett, W.C. Dietary saturated fats and their food sources in relation to the risk of coronary heart disease in women. Am. J. Clin. Nutr. 1999, 70, 1001-1008. [CrossRef] [PubMed]

6. Vahmani, P.; Ponnampalam, E.N.; Kraft, J.; Mapiye, C.; Bermingham, E.N.; Watkins, P.J.; Proctor, S.D.; Dugan, M.E. Bioactivity and health effects of ruminant meat lipids: Invited Review. Meat Sci. 2020, 165, 108114. [CrossRef] [PubMed]

7. Hurtaud, C.; Faucon, F.; Couvreur, S.; Peyraud, J.-L. Linear relationship between increasing amounts of extruded linseed in dairy cow diet and milk fatty acid composition and butter properties. J. Dairy Sci. 2010, 93, 1429-1443. [CrossRef] [PubMed]

8. Shingfield, K.; Bonnet, M.; Scollan, N. Recent developments in altering the fatty acid composition of ruminant-derived foods. Animal 2013, 7, 132-162. [CrossRef] 
9. Moran, C.; Morlacchini, M.; Keegan, J.D.; Warren, H.; Fusconi, G. Dietary supplementation of dairy cows with a docosahexaenoic acid-rich thraustochytrid, Aurantiochytrium limacinum: Effects on milk quality, fatty acid composition and cheese making properties. J. Anim. Feed. Sci. 2019, 28, 3-14. [CrossRef]

10. Gebreyowhans, S.; Lu, J.; Zhang, S.; Pang, X.; Lv, J. Dietary enrichment of milk and dairy products with n-3 fatty acids: A review. Int. Dairy J. 2019, 97, 158-166. [CrossRef]

11. Swanson, D.; Block, R.; Mousa, S.A. Omega-3 Fatty Acids EPA and DHA: Health Benefits Throughout Life. Adv. Nutr. 2012, 3, 1-7. [CrossRef]

12. Alexander, D.D.; Miller, P.E.; Van Elswyk, M.E.; Kuratko, C.N.; Bylsma, L.C. A Meta-Analysis of Randomized Controlled Trials and Prospective Cohort Studies of Eicosapentaenoic and Docosahexaenoic Long-Chain Omega-3 Fatty Acids and Coronary Heart Disease Risk. Mayo Clin. Proc. 2017, 92, 15-29. [CrossRef]

13. Harris, W.S.; Del Gobbo, L.; Tintle, N.L. The Omega-3 Index and relative risk for coronary heart disease mortality: Estimation from 10 cohort studies. Atherosclerosis 2017, 262, 51-54. [CrossRef] [PubMed]

14. Mocking, R.J.T.; Harmsen, I.; Assies, J.; Koeter, M.W.J.; Ruhé, H.G.; Schene, A.H. Meta-analysis and meta-regression of omega-3 polyunsaturated fatty acid supplementation for major depressive disorder. Transl. Psychiatry 2016, 6, e756. [CrossRef]

15. Hanson, S.; Thorpe, G.; Winstanley, L.; Abdelhamid, A.S.; Hooper, L.; on behalf of the PUFAH group. Omega-3, omega-6 and total dietary polyunsaturated fat on cancer incidence: Systematic review and meta-analysis of randomised trials. Br. J. Cancer 2020, 122, 1260-1270. [CrossRef] [PubMed]

16. Kolanowski, W.; Laufenberg, G. Enrichment of food products with polyunsaturated fatty acids by fish oil addition. Eur. Food Res. Technol. 2006, 222, 472-477. [CrossRef]

17. Kim, E.J.; Huws, S.; Lee, M.; Wood, J.D.; Muetzel, S.; Wallace, R.J.; Scollan, N.D. Fish Oil Increases the Duodenal Flow of Long Chain Polyunsaturated Fatty Acids and trans-11 18:1 and Decreases 18:0 in Steers via Changes in the Rumen Bacterial Community. J. Nutr. 2008, 138, 889-896. [CrossRef] [PubMed]

18. Shingfield, K.J.; Kairenius, P.; Ärölä, A.; Paillard, D.; Muetzel, S.; Ahvenjärvi, S.; Vanhatalo, A.; Huhtanen, P.; Toivonen, V.; Griinari, J.M.; et al. Dietary Fish Oil Supplements Modify Ruminal Biohydrogenation, Alter the Flow of Fatty Acids at the Omasum, and Induce Changes in the Ruminal Butyrivibrio Population in Lactating Cows. J. Nutr. 2012, 142, 1437-1448. [CrossRef]

19. Tacon, A.G.; Metian, M. Global overview on the use of fish meal and fish oil in industrially compounded aquafeeds: Trends and future prospects. Aquaculture 2008, 285, 146-158. [CrossRef]

20. AbuGhazaleh, A.; Potu, R.; Ibrahim, S. Short communication: The effect of substituting fish oil in dairy cow diets with docosahexaenoic acid-micro algae on milk composition and fatty acids profile. J. Dairy Sci. 2009, 92, 6156-6159. [CrossRef]

21. Leyland, B.; Leu, S.; Boussiba, S. Are Thraustochytrids algae? Fungal Biol. 2017, 121, 835-840. [CrossRef]

22. Gupta, A.; Barrow, C.J.; Puri, M. Omega-3 biotechnology: Thraustochytrids as a novel source of omega-3 oils. Biotechnol. Adv. 2012, 30, 1733-1745. [CrossRef]

23. Keegan, J.; Currie, D.; Knox, A.; Moran, C. Docosahexaenoic Acid Included in Layer Feed as an Unextracted Aurantiochytrium limacinum Biomass Is Efficiently Transferred to Eggs When Provided in Mash or Pellet Form. J. Appl. Poult. Res. 2019, 28, 1069-1077. [CrossRef]

24. Moran, C.A.; Morlacchini, M.; Keegan, J.D.; Fusconi, G. The effect of dietary supplementation with Aurantiochytrium lim-acinum on lactating dairy cows in terms of animal health, productivity, and milk composition. J. Anim. Physiol. Anim. Nutr. 2018, 102, 576-590. [CrossRef]

25. Franklin, S.T.; Martin, K.R.; Baer, R.J.; Schingoethe, D.J.; Hippen, A.R. Dietary marine algae (Schizochytrium sp.) increases concentrations of conjugated linoleic, docosahexaenoic and transvaccenic acids in milk of dairy cows. J. Nutr. 1999, 129, 2048-2054. [CrossRef]

26. Bichi, E.; Hervás, G.; Toral, P.G.; Loor, J.; Frutos, P. Milk fat depression induced by dietary marine algae in dairy ewes: Persistency of milk fatty acid composition and animal performance responses. J. Dairy Sci. 2013, 96, 524-532. [CrossRef]

27. Jenkins, T.C.; Wallace, R.J.; Moate, P.; Mosley, E.E. Board-invited review: Recent advances in biohydrogenation of unsaturated fatty acids within the rumen microbial ecosystem. J. Anim. Sci. 2008, 86, 397-412. [CrossRef] [PubMed]

28. Goering, H.K.; Van Soest, P.J. Forage fiber analyses: Apparatus, Ragents, Procedures, and Some Applications (No. 379). In Agricultural Research Service; US Department of Agriculture: Honolulu, HI, USA, 1970.

29. Apajalahti, J.; Vienola, K.; Raatikainen, K.; Holder, V.; Moran, C.A. Conversion of branched-chain amino acids to corre-sponding isoacids-An in vitro tool for estimating ruminal protein degradability. Front. Vet. Sci. 2019, 6, 311. [CrossRef] [PubMed]

30. Nadkarni, M.A.; Martin, F.E.; Jacques, N.A.; Hunter, N. Determination of bacterial load by real-time PCR using a broad-range (universal) probe and primers set. Microbiology 2002, 148, 257-266. [CrossRef]

31. Cadillo-Quiroz, H.; Brauer, S.; Yashiro, E.; Sun, C.; Yavitt, J.; Zinder, S. Vertical profiles of methanogenesis and methanogens in two contrasting acidic peatlands in central New York State, USA. Environ. Microbiol. 2006, 8, 1428-1440. [CrossRef]

32. Rinttila, T.; Kassinen, A.; Malinen, E.; Krogius, L.; Palva, A. Development of an extensive set of 16S rDNA-targeted primers for quantification of pathogenic and indigenous bacteria in faecal samples by real-time PCR. J. Appl. Microbiol. 2004, 97, 1166-1177. [CrossRef]

33. Tajima, K.; Aminov, R.I.; Nagamine, T.; Matsui, H.; Nakamura, M.; Benno, Y. Diet-Dependent Shifts in the Bacterial Population of the Rumen Revealed with Real-Time PCR. Appl. Environ. Microbiol. 2001, 67, 2766-2774. [CrossRef] 
34. Sylvester, J.T.; Karnati, S.K.R.; Yu, Z.; Morrison, M.; Firkins, J.L. Development of an Assay to Quantify Rumen Ciliate Protozoal Biomass in Cows Using Real-Time PCR. J. Nutr. 2004, 134, 3378-3384. [CrossRef]

35. O'Fallon, J.V.; Busboom, J.R.; Nelson, M.L.; Gaskins, C.T. A direct method for fatty acid methyl ester synthesis: Application to wet meat tissues, oils, and feedstuffs. J. Anim. Sci. 2007, 85, 1511-1521. [CrossRef]

36. Givens, D.I.; Cottrill, B.R.; Davies, M.; Lee, P.A.; Mansbridge, R.J.; Moss, A.R. Sources of n-3 polyunsaturated fatty acids ad-ditional to fish oil for livestock diets-A review. Nutr. Abstr. Rev. 2000, 70, 1-19.

37. Moallem, U. Invited review: Roles of dietary n-3 fatty acids in performance, milk fat composition, and reproductive and immune systems in dairy cattle. J. Dairy Sci. 2018, 101, 8641-8661. [CrossRef]

38. Papadopoulos, G.; Goulas, C.; Apostolaki, E.; Abril, R. Effects of dietary supplements of algae, containing polyunsaturated fatty acids, on milk yield and the composition of milk products in dairy ewes. J. Dairy Res. 2002, 69, 357-365. [CrossRef] [PubMed]

39. Boeckaert, C.; Vlaeminck, B.; Fievez, V.; Maignien, L.; Dijkstra, J.; Boon, N. Accumulation of trans C 18:1 Fatty Acids in the Rumen after Dietary Algal Supplementation Is Associated with Changes in the Butyrivibrio Community. Appl. Environ. Microbiol. 2008, 74, 6923-6930. [CrossRef]

40. Khas-Erdene, Q.; Wang, J.; Bu, D.; Wang, L.; Drackley, J.; Liu, Q.; Yang, G.; Wei, H.; Zhou, L. Short communication: Responses to increasing amounts of free $\alpha$-linolenic acid infused into the duodenum of lactating dairy cows. J. Dairy Sci. 2010, 93, 1677-1684. [CrossRef] [PubMed]

41. Toral, P.; Frutos, P.; Hervás, G.; Gómez-Cortés, P.; Juárez, M.; de la Fuente, M. Changes in milk fatty acid profile and animal performance in response to fish oil supplementation, alone or in combination with sunflower oil, in dairy ewes. J. Dairy Sci. 2010, 93, 1604-1615. [CrossRef] [PubMed]

42. Toral, P.; Bernard, L.; Belenguer, A.; Rouel, J.; Hervás, G.; Chilliard, Y.; Frutos, P. Comparison of ruminal lipid metabolism in dairy cows and goats fed diets supplemented with starch, plant oil, or fish oil. J. Dairy Sci. 2016, 99, 301-316. [CrossRef]

43. Reynolds, C.; Dürst, B.; Lupoli, B.; Humphries, D.; Beever, D. Visceral Tissue Mass and Rumen Volume in Dairy Cows During the Transition from Late Gestation to Early Lactation. J. Dairy Sci. 2004, 87, 961-971. [CrossRef]

44. Moran, C.; Keegan, J.; Jacques, K.; Hart, H. PSXI-4 Minimum inhibitory concentration of a heterotrophically grown, dried microalgae powder (All-G-Rich ${ }^{\circledR}$ ) and extracted microalgal oil against selected intestinal microorganisms. J. Anim. Sci. 2018, 96, 360-361. [CrossRef]

45. Maia, M.R.; Chaudhary, L.C.; Bestwick, C.S.; Richardson, A.J.; McKain, N.; Larson, T.R.; Graham, I.A.; Wallace, R.J. Toxicity of unsaturated fatty acids to the biohydrogenating ruminal bacterium, Butyrivibrio fibrisolvens. BMC Microbiol. $2010,10,52$. [CrossRef] [PubMed]

46. Jeyanathan, J.; Escobar, M.; Wallace, R.J.; Fievez, V.; Vlaeminck, B. Biohydrogenation of 22:6n-3 by Butyrivibrio proteoclasticus P18. BMC Microbiol. 2016, 16, 104. [CrossRef] [PubMed]

47. Toral, P.G.; Hervás, G.; Carreño, D.; Leskinen, H.; Belenguer, A.; Shingfield, K.; Frutos, P. In vitro response to EPA, DPA, and DHA: Comparison of effects on ruminal fermentation and biohydrogenation of 18-carbon fatty acids in cows and ewes. J. Dairy Sci. 2017, 100, 6187-6198. [CrossRef] [PubMed]

48. Vargas, J.E.; Andrés, S.; Snelling, T.J.; López-Ferreras, L.; Yáñez-Ruíz, D.R.; Garcia-Estrada, C.; Lopez, S. Effect of Sunflower and Marine Oils on Ruminal Microbiota, In vitro Fermentation and Digesta Fatty Acid Profile. Front. Microbiol. 2017, 8, 1124. [CrossRef] [PubMed]

49. Apajalahti, J.H.A.; Salkinoja-Salonen, M.S. Absorption of pentachlorophenol (PCP) by bark chips and its role in microbial PCP degradation. Microb. Ecol. 1984, 10, 359-367. [CrossRef]

50. Huws, S.A.; Lee, M.R.; Muetzel, S.M.; Scott, M.B.; Wallace, R.J.; Scollan, N.D. Forage type and fish oil cause shifts in rumen bacterial diversity. FEMS Microbiol. Ecol. 2010, 73, 396-702. [CrossRef]

51. Sinedino, L.D.P.; Honda, P.M.; Souza, L.R.L.; Lock, A.L.; Boland, M.P.; Staples, C.R.; Thatcher, W.W.; Santos, J.E.P. Effects of supplementation with docosahexaenoic acid on reproduction of dairy cows. Reproduction 2017, 153, 707-723. [CrossRef]

52. Carreño, D.; Toral, P.G.; Pinloche, E.; Belenguer, A.; Yáñez-Ruiz, D.R.; Hervás, G.; McEwan, N.R.; Newbold, C.J.; Frutos, P. Rumen bacterial community responses to DPA, EPA and DHA in cattle and sheep: A comparative in vitro study. Sci. Rep. 2019, 9, 11857. [CrossRef] [PubMed]

53. Chen, L.; Wang, H. Advances in the metabolism and regulation of lactic acids in the rumen. Pratacult. Sci. 2016, 33, 972-980.

54. Durmic, Z.; Moate, P.J.; Eckard, R.; Revell, D.K.; Williams, R.; Vercoe, P.E. In vitro screening of selected feed additives, plant essential oils and plant extracts for rumen methane mitigation. J. Sci. Food Agric. 2014, 94, 1191-1196. [CrossRef] [PubMed]

55. Fievez, V.; Dohme, F.; Danneels, M.; Raes, K.; Demeyer, D. Fish oils as potent rumen methane inhibitors and associated effects on rumen fermentation in vitro and in vivo. Anim. Feed. Sci. Technol. 2003, 104, 41-58. [CrossRef]

56. Fievez, V.; Boeckaert, C.; Vlaeminck, B.; Mestdagh, J.; Demeyer, D. In vitro examination of DHA-edible micro-algae: 2 . Effect on rumen methane production and apparent degradability of hay. Anim. Feed. Sci. Technol. 2007, 136, 80-95. [CrossRef]

57. Henning, P.; Horn, C.; Steyn, D.; Meissner, H.; Hagg, F. The potential of Megasphaera elsdenii isolates to control ruminal acidosis. Anim. Feed. Sci. Technol. 2010, 157, 13-19. [CrossRef]

58. Maia, M.R.G.; Chaudhary, L.C.; Figueres, L.; Wallace, R.J. Metabolism of polyunsaturated fatty acids and their toxicity to the microflora of the rumen. Antonie Leeuwenhoek 2007, 91, 303-314. [CrossRef] 